\title{
Determinants of competence development in accounting in upper secondary education
}

\author{
Christoph Helm ${ }^{*}$
}

*Correspondence: christoph.helm@jku.at Department of Education and Educational Psychology, Johannes Kepler University of Linz, Altenberger Straße 69, 4040 Linz, Austria

\begin{abstract}
Given the lack of research on predictors of students' learning success in vocational domains, the present study aims to identify determinants of student competence growth in the subject Accounting. Based on theoretical models (e.g., basic deep structure dimensions of instructional quality, self-enhancement theory, self-determination theory) and related published research, we hypothesized that students' improvement could be best predicted by their prior knowledge and cognitive abilities, followed by self-concept, cognitive learning strategies, motivational regulations and perceptions of learning environment characteristics. In particular, we aimed to ascertain whether aspects of the learning environment determine student competency development in Accounting, controlling for effects of key student characteristics. By means of threelevel models involving repeated measurements, we analysed data from 487 students ( $74 \%$ female; age $_{\mathrm{t} 0}: M=14.40$ years, $S D=0.74$ ) from Austrian commercial upper secondary schools in grades 9 through 11 . Most of our hypotheses are supported by this data, and thus we could answer our research question as follows: The students' proficiency in mathematics, their grades from the previous school year, perceived cognitive activation and support from teachers of their basic psychological needs most strongly predicted student initial status and growth in accounting competence. However, against all expectations, cognitive learning strategies and class mean of perceived student-centred instruction were not, or were negatively, related to their competence, which indicates that the latter was perceived more often in low-performing classes. As expected, student intrinsic motivation and academic self-concept were related to competence in accounting. Contradictory to correlation analysis, time spent on learning in class was not significantly related to competence development at any hierarchical level of the multilevel analysis. We discuss our results within the limitations of this present study, and their consequences for teaching practice.
\end{abstract}

Keywords: Competence development, Accounting, Three-level multilevel analysis with repeated measurements, Determinants of academic achievement, Vocational education

\section{Background}

Since economic activities constitute an essential part of everyday life and they govern important aspects of society such as politics, a central goal of schooling is to make this domain accessible to students. Acting in an economically competent and responsible

(c) $2015 \mathrm{Helm}$. This article is distributed under the terms of the Creative Commons Attribution 4.0 International License (http:// creativecommons.org/licenses/by/4.0/), which permits unrestricted use, distribution, and reproduction in any medium, provided you give appropriate credit to the original author(s) and the source, provide a link to the Creative Commons license, and indicate if changes were made. 
way requires knowing how the world of business works. Educating young people about this is an important objective of Austria's business-oriented upper secondary education (kaufmännische berufsbildende mittlere und höhere Schulen, BMHS). According to the "Education at a Glance" report (OECD 2012), Austria is one of the OECD countries with the largest share of students in vocationally oriented upper secondary education. This might be partially due to the long tradition of commercial education in Austria. In 1770, the first commercial upper secondary schools was founded under Empress Maria Theresia with the goal to educate 15-20 year-old students in subjects such as Business, Economics and Accounting (Stock 2014). Since 1962, commercial upper secondary schools have had a separate legal basis in the Austrian (vocational) school system at secondary stage two. Today 87,375 students attend business-related schools, so-called "kaufmännische Schulen/wirtschaftsberufliche Schulen" (BMBF 2014). Upon entering these schools, students choose between three-year (without Matura, i.e., without higher education entrance qualification; referred to as BMS: berufsbildende mittlere Schule) and five-year (with Matura; referred to as BHS: berufsbildende höhere Schule) tracks.

Although vocational education is often seen as the basis of human education (Kerschensteiner 1904), student competencies in these domains are surprisingly seldom the subject of research. In line with the orientation towards output undergone by German-speaking educational systems, there is, of course, increased research into vocational competencies using modern psychometric methods (Seeber et al. 2010). However, identifying the determinants of student competence development in business-related academic subjects has, so far, been neglected. This is especially true for the development of specific students in the above-mentioned subjects in Austria. To the best of our knowledge, there are only cross-sectional studies on economic everyday knowledge (Schumann and Eberle 2014) and business-related knowledge of students from apprenticeship and dual vocational training systems, respectively (Winther 2010). One exception is the longitudinal study by Lehmann and Seeber (2007), which, however, does not identify determinants of student competency development. To summarise, published studies in VET concentrate on specific aspects (such as learning motivation, Helm 2015, and mathematics attainment, Seeber 2013), work with cross-sectional designs, or investigate relatively small samples. The present study overcomes these shortcomings by referring to prominent theoretical models (such as the model of instructional quality, Klieme et al. 2006) and applying complex linear growth curve models in order to answer the following research question: How do aspects of the learning environment (cognitive activation, classroom management and supportive climate) determine student competency development in accounting when the effects of key student characteristics, such as their prior attainment in accounting and mathematics, self-concept, learning strategies, motivational regulation, and socioeconomic status, in the initial 3 years of Austrian vocational education are controlled for?

\section{Theory and research}

In order to answer our research question, we followed the prominent "Offer and Use Model" (Helmke 2009). The model goes back to Carroll (1963), who tried to explain academic achievement as a function of the ratio of needed learning time and actually invested learning time. Carroll's model was further developed by others, and it was Walberg (1981) who first showed based on a systematic review of research results that academic achievement is 
a (non-linear) product of different (scarcely compensative) factors, such as student, instructional and contextual characteristics. In line with this approach, the "Offer and Use Model" represents the actual knowledge of conditions and consequences of educational instruction and how the factors are connected to each other (Helmke and Schrader 2006, p. 7). Due to its abstractness, the model lacks theoretical foundation and is thus more of a framework that needs to be filled with theories-which is exactly what we do in the next section. Following the paper "Determinanten der Schulleistung/Determinants of Academic Performance" by Schrader and Helmke (2008), we selected central, proximal predictors of student academic achievement (such as student characteristics) as well as more distal predictors (such as instructional characteristics). For each of them, we briefly describe the theories/theoretical models that explain their effects on student academic performance. Additionally, for each predictor we refer to published research in accounting. With regard to research findings, it should be noted that we are aware of the extensive efforts in generic domains (see, e.g., Schrader and Helmke 2008). Multidisciplinary reviews of meta-analyses (Hattie 2009) provide a clear picture of which of the many possible variables influence students' academic performance. We use these findings as starting points to frame our theoretical assumptions, but we do not assume that all findings from other domains also apply to business-related domains, in particular to accounting, which is the focus of our paper. We assume that there are significant overlaps, but also some accounting-specific dynamics in the data. These may be due to mainly two obvious characteristics of accounting instruction. First, unlike those taught in subjects such as Mathematics and Reading, concepts taught in Accounting are restricted to the domain. Second, there is a strong emphasis on practice and repetition in Accounting. Götzl, Jahn, and Held (2013, p. 13) observed 125 accounting lessons and analysed them with regard to the average duration of different instructional phases. Unsurprisingly, they found that a significantly larger share of time is devoted to practising in accounting than in domains such as business and economics. For these reasons, the novelty of the present paper lies among others in the domain-specific investigations which are needed due to the fact that instruction and learning in accounting is not comparable to other domains.

\section{Theoretical and empirical foundations of effects of central determinants Indicators related to student cognitive ability}

Indicators of student cognitive ability such as prior content knowledge, IQ, prior attainment in mathematics and grades in previous school years/semesters (as indicators of school engagement and resource of positive self-efficacy beliefs) are paramount to success in school (cf. Schrader and Helmke 2008; for the Austrian situation see Helm et al. 2015b). There are several theories supporting this assumption:

\section{Prior content knowledge}

Theory The constructivist view of learning assumes that students build their conceptual understanding not by repeating instructed knowledge, but by interactively relating prior experience and knowledge to new concepts. According to Piaget's theory of cognitive and affective development $(1929,1970)$, individuals seek to incorporate new concepts into existing schemata (i.e., assimilation) or to reframe existing schemata to fit new concepts (i.e., accommodation) in order to avoid cognitive dissonances that cause unease. Thus, it is fundamental to educational instruction (1) to explicitly discuss the relations 
between a new concept being taught and others that have already been taught and (2) to explicitly show the relations between elements (with which students should be familiar) within the concept, in order to make new concepts accessible. Furthermore, Vygotskij's (1978) theory of the zone of proximal development postulates that learning takes place when learners "are always being challenged to increase their understanding of the problem while never being asked to do more than they can do" (Berndt 1997, p. 323). Therefore, tasks and exercises need to be constructed such that they address prior knowledge and competencies.

Research Regarding accounting, there are only few studies examining the effect of content-specific prior knowledge on student academic achievement. Winther and Achtenhagen (2008) argued that domain-related basic and procedural knowledge is important. In later studies (Winther 2010; Winther et al. 2013), they reported significant correlations between prior knowledge and domain-specific performance in accounting and controlling (although they were relatively weak, $r=0.18$ ). Additionally, they found for a sample of 340 students from commercial secondary schools ("Wirtschaftsgymnasium") in Germany that those with a preparatory commercial training did significantly better in a test assessing conceptual and procedural economic literacy than those without this prior education. In both studies, prior knowledge was assessed using a specifically designed instrument that assesses economic literacy and numeracy (Winther 2010). Based on a sample of 351 students from Austrian BMHS, Helm (2015) showed that accounting competence is relatively stable $\left(b^{*}=0.63\right.$; in the following * refers to standardized beta values) at the end of grades 9 and 10. In addition, Helm (2014b) revealed-controlling for several other aspects of instructional quality and student characteristics-that teachers' consideration of prior knowledge has a high impact on learning success in grade $9(b=0.41)$. Both studies used the same instrument as the present study (see below). In contrast, in the "SoLe" study, Sembill (2004) did not observe an effect of prior knowledge on a learning-goal-oriented test and on complex problem-solving in the human resources domain. This might in part be due to the small sample of 30 students from dual vocational training as commercial office assistants. However, in relation to the accounting concept of "preparatory closing entries", Seifried (2004) showed in the same study that students' prior knowledge explained $56 \%$ of the score variation in a learning-goal-oriented knowledge test. Again, the sample was small $(\mathrm{N}=9)$. Given that the presented studies use different instruments to assess both prior knowledge and accounting abilities, the findings are not comparable. All in all they did not find overly strong relations between content-specific knowledge and academic achievement in accounting. Nevertheless, we conclude-mainly based on theory-that prior knowledge and the use of domain-specific concepts, terms and procedures play a major role in predicting academic achievement in accounting.

\section{Cognitive abilities (intelligence)}

Theory Intelligence research (see Hunt 2000, p. 123) divides intelligence into two main levels: one including elementary information-processing actions and one including "more broadly defined capabilities, such as holding and accessing information in short- and long-term memory and, [...] crystallized intelligence (Gc), fluid intelligence (Gf), and visual-spatial reasoning ability (Gv)". Based on this distinction, educational 
researchers (Schrader and Helmke 2008) argue that students with higher crystallised and fluid intelligence possess better knowledge- and experience-related thinking and learning strategies and higher basic intellectual competencies. Hence, they recognise regularities in tasks more quickly, from which follows that these students perform better in academic achievement tests.

Research The impact of basic cognitive abilities on academic achievement has been widely proven. Jordan and Brownlee (1981) calculated an effect size of 1.28 between Piagetian programmes and school achievement tests, which ranks at second place in Hattie's (2009) overview of meta-analyses. In addition, there is a vast body of research on the relations between cognitive abilities assessed using "intelligence tests" (e.g., Kuncel et al. 2001, 2004; Linn and Hastings 1984); for instance, Phillipson and Phillipson (2012, p. 496) stated that "In several reviews of this literature (Jensen 1998a, b; Kuncel et al. 2004; Kytala and Lehto 2008; Strenze 2007; Taub et al. 2008), the authors concluded that cognitive ability is the most important, albeit imperfect, predictor of achievement in many academic subjects". To the best of our knowledge, in the domain of accounting only two such studies have been published. (1) Schumann and Eberle (2014) showed that there is a correlation between student accounting competence and KFT (Heller and Perleth 2000) scores, although it is somewhat small $(r=0.14)$ compared to correlations found in other domains like mathematics $(r=0.50)$. (2) In contrast, Lehmann and Seeber (2007, p. 121) found no association $\left(R^{2}=0.3 \%\right)$ between KFT and accounting performance in a sample of students from vocational training in the "business and public administration" field, and argued that prior knowledge plays a more important role in this domain. Further, note that-according to research from cognitive psychology-prior content knowledge can compensate to some extent for a lack of intelligence (Schneider et al. 1989; Staub and Stern 2002; Stern 2003). Again, these findings highlight the importance of content knowledge in accounting. In comparison to the effects found for IQ, prior content knowledge seems to play a major role. For this reason, as well as for resource-related reasons (test time), we did not collect data on student IQ.

\section{Mathematical abilities}

Theory The applicability and transferability of mathematical concepts to the domain of accounting is undisputed and obvious. Seeber (2013, p. 73) argued that in a number of professions it is not possible to solve job-specific tasks without applying mathematical routines, algorithms and models. This is also true for accounting: percentages, (inverse) accounting, basic arithmetic and compound interest calculation represent mathematical key concepts that are essential to solving accounting-specific problems. Further, in mathematics lessons students develop problem-solving strategies and model real-world problems in a different language. These abilities are also relevant in accounting (e.g., the so-called "process-oriented accounting approach" calls for modelling inter- and intracorporate processes and corporate support processes). Quite similarly, Winther (2010, p. 168 ) argues that procedural knowledge of mathematical situations (= economic numeracy) represents an important aspect of economical literacy, the ability of cultural participation in economic related contexts.

Research Given the importance of mathematical competencies in student accounting competence development, the journal "Berufs- und Wirtschaftspädagogik" published a 
special issue dedicated to research in that area (e.g., Seeber 2013; Winther et al. 2013). For instance, based on data from the "ULME III" project, Seeber (2013, p. 86) showed that mathematical ability predicts accounting/controlling competency with an effect size of $b^{*}=0.34$ when reading and cognitive abilities (KFT) are controlled for; reading literacy had no direct influence (see also Seeber and Lehmann 2013 for findings in the economic domain). This analysis was based on a sample of dual-system students from seven different professions in the field of "business and public administration". Winther et al. (2013, p. 144) showed-based on a sample of 353 full-time academic-track students-that economic numeracy (i.e., the ability to apply basic mathematical algorithms) is central to mastering specific tasks from the accounting/controlling domain. The correlation between student performance in a prior-knowledge test and a post-test in accounting/controlling is weaker when economic numeracy is controlled for. In previous studies, Helm (2014b) showed that students' scores in a mathematics test and their mathematics grades are substantially correlated with their degree of accounting competence. At the student level, the correlations were $r=0.30$ (mathematics test) and $r=0.35$ (mathematics grades). At the class level, the correlations were even higher with $r=0.40$ (mathematics test) and $r=0.49$ (mathematics grades). However, using data from a representative Swiss sample, Schumann and Eberle (2014, p. 117) found a zerocorrelation between accounting and mathematics. This might be due to the fact that the test aimed to measure broad, basic "everyday" skills, and was thus based predominantly on declarative knowledge in economics and business. Based on the theoretical models of cognitive development and intelligence research and economic literacy, and their empirical evidence, we formulate the following hypothesis:

H1: Students' cognitive abilities as indicated by prior accounting and maths achievement and grades in the previous school year are the strongest predictor of student competence development in accounting from grades 9 through 11.

\section{Student self-concept}

Theory To argue the causal relation between an individual's self-concept and academic achievement, the literature frequently relies on the self-enhancement and skill-development model (Calsyn and Kenny 1977). Although the perception of one's academic self is undoubtedly partly a product of previous educational experiences (skill-development model), there are several reasons for arguing that beliefs about one's self can be used to predict academic achievement (self-enhancement model): Helmke and van Aken (1995, p. 624) pointed out that "a high self-concept of ability may be a favourable precondition for the initiation and persistence of effort in learning and achievement situations" and that "students with a low self-concept might avoid critical learning situations that could threaten their self-concept and thus might show less effort in school [wherefore they] are prone to develop failure-avoiding tactics" which in the long run "impair academic achievement".

Research Indeed, researchers found substantial relations of $r=0.40 / b=0.26$ between self-efficacy/academic self-concept and performance (Helm 2014a; Nüesch and Metzger 2010) also in business-related domains. Following the assumptions of the self-enhancement model, we hypothesize as follows: 
H2: Students' academic self-concept in accounting is significantly related to student competency development in accounting, even when controlling for student characteristics, such as their cognitive abilities.

\section{Student (meta-)cognitive learning strategies}

Theory Most models of self-regulated learning/learners such as the self-regulation model by Schunk and Zimmerman (2008) and the structural model of behaviour by Konrad (2008) assume a cyclical process of action and reflection in the learning process. Using cognitive and meta-cognitive learning strategies learners themselves activate, sustain and regulate resources such as appropriate problem-solving strategies to achieve (mostly cognitive) learning goals or other desired states (e.g., Schiefele and Pekrun 1996). Thus, from a theoretical point of view, we assume that successful learners do not only possess high cognitive abilities but also rely on a more comprehensive tool box of strategies and are more capable of applying strategies that best suit their current learning situation and abilities (Metzger 2014).

Research With regard to accounting, hardly any research has investigated the relation between students' use of learning strategies and their learning success. Nüesch and Metzger (2010, p. 48) reported in a small intervention study that "low to medium positive correlations were found between academic performance in economic and business oriented subjects and strategies such as dealing with test anxiety, test solving strategies, elaboration and self-efficacy". In the context of the Learning in Open and Traditional Educational Settings (LOTUS) study, which investigated the learning process and competence development of upper secondary students and which provides the basis for this paper, we analysed the effect of student (meta-)cognitive learning strategies on their accounting competence development. Contrary to our expectations, neither for grade 9 nor for grade 10 were we able to identify significant strategies. However, we showed that, in addition to student characteristics, teacher support in task analysis positively influenced learning in accounting. Thus, analysing tasks with respect to what is asked, what is given and which prior knowledge a student possesses before actually solving them is an important learning strategy in accounting. Based on the abovementioned models of self-regulation and related research, we assume the following:

H3: Students' use of learning strategies is significantly related to student competency development in accounting, even when controlling for student characteristics such as their cognitive abilities.

\section{Student motivational characteristics}

Theory Research on motivational aspects of teaching and learning is dominated by selfdetermination theory (SDT; Deci and Ryan 1985), especially in VET research (see Helm 2015 for an overview). Since other motivational theories have scarcely been studied, we focus on SDT. Deci and Ryan (1993, p. 233) believe that high-quality learning relies on intrinsic and/or integrated ${ }^{1}$ regulation. Higher motivation-both extrinsic and intrinsic-leads to more effortful engagement in school learning (e.g., Vansteenkiste et al.

${ }^{1}$ Integrated regulation refers to motivation that is driven by goals, values and strategies that are integrated in one's own self. Identified regulation refers to actions that are motivated by the feeling that something should be done because one feels that it is important (Deci and Ryan 1993). 
2004). However, intrinsic learning motivation is more strongly connected to positive emotions (subject interest, school satisfaction, etc.) than extrinsic motivation, and therefore leads to better academic achievement (ibid.).

Research Although this relation has already been established in other domains (e.g., Grolnick and Ryan 1987; Jang et al. 2012; Um et al. 2005; Valås and Søvik 1993; Vansteenkiste et al. 2005), we found only one publication in accounting: Winther (2006, p. 212) showed that teacher support of basic psychological needs (such as the need for autonomy) strongly predicts intrinsic motivation, but is not related to school grades. However, factors indicative of the motivational state, such as the willingness to make an effort, do predict grades. In the LOTUS study only "identified motivation" (one form of motivational regulation according to SDT: e.g., acknowledging and adopting learning goals) was related to the performance in an accounting test, but not intrinsic motivation. Seifried (2004, p. 212) did also not find significant relationships. However, Metz-Göckel (2001) showed that student perception of teacher support of their psychological need for competence (e.g., by informative feedback) was moderately correlated with their grades in the subject Business. Additionally, Schumann and Eberle (2014, for Accounting) and Kotte and Lietz (1998, for Economics) showed-based on empirical data-that one's attitude towards the domain is one of the most important predictors of academic performance. Based on the above-mentioned models of self-determination theory and related research, we assume that:

H4: Students' intrinsic regulation is significantly related to student competency development in accounting, even when controlling for student characteristics, such as their cognitive abilities.

\section{Gender}

Theoretical assumption The commercial school types (HAK, HLW) analysed in the present paper are more popular with, and thus dominated by, girls, whereas the technical school track (HTL), which is more attractive for well-performing male students, was not part of the current sample. Thus, we assume a selection effect that leads to higher performance among girls. This expectation is in contrast with published research: On average, male students perform better in business-related domains (Schumann and Eberle 2014: Cohens $d=0.34$; see also Brandlmaier et al. 2006; Beck and Krumm 1998; Freundlinger and Eckstein 1992; Seeber 2008). Based on the above-mentioned assumptions, we expect that:

H5: In accounting, female students develop significantly better than male students.

\section{Economic, social and cultural status}

Theory Differences in academic achievement that are related to students' social backgrounds are frequently explained by human capital theories (Coleman 1988; Bourdieu 1983): to the extent to which parents are capable of investing social and cultural capital in their children, differences in academic performances are explained. Hattie (2009, pp. 74-76) argued that the effect of economic, social and cultural status (ESCS) or resources 
is highest in pre-school and early school years. Students from different ESCS groups are differently equipped in terms of what they have learnt from their parents or another domestic reference person. Hattie referred, for instance, to lower verbal skills (less extensive vocabulary, less knowledge about the educational language), lower expectations and lower commitment in school. One explanation is that low ESCS often goes together with low domestic intellectual and socio-psychological stimulation (Iverson and Walberg 1982). Research findings in the business-related vocational training domains regarding the impact of ESCS are limited: there is only the study by Kotte and Lietz (1998), who found that the parents' highest level of education is one of the most important predictors. In contrast, the LOTUS study stated that ESCS is not related to student performance at all. Since Hattie reported that the effects of socioeconomic variables are the strongest in the early years, one might argue that learning success in adolescence is largely uncoupled from ESCS. Nevertheless, based on the above-mentioned human capital theories and research findings, we hypothesize the following:

H6: Students' economic, social and cultural statuses are significantly related to student competency development in accounting.

\section{Learning environment characteristics}

Theory There is a huge body of literature on effective teaching and instruction. A prominent model of instructional quality is the "theoretical model of basic (deep structure) dimensions of instructional quality", described in the work of Klieme et al. (2006). "Building on both process-product and constructivist research paradigms, taking into account cognitive as well as motivational theories, our model of instructional quality [...] identifies three basic ('deep structure') quality dimensions and links them to students' learning outcomes" (Klieme et al. 2009, pp. 139-141). The three basic dimensions are cognitive activation, classroom management and supportive climate. Cognitive activation refers to a pedagogical practice "that encourages students to engage in (co-)constructive and reflective higher-level thinking and thus to develop an elaborated, content-related knowledge base" (ibid., p. 140-141). Classroom management, structure and clarity are preconditions for cognitive activation in class. This criterion refers to teaching and learning processes that "take place in an efficient and orderly fashion, with smooth transitions and little time spent dealing with problems of inattentiveness or resistance" (ibid., p. 141). The term supportive climate relates to teacher behaviour that supports the students' needs for autonomy, competence and relatedness (ibd., p. 141).

Research Whereas this model and its promoted aspects of effective learning environments have already been evaluated in generic domains such as mathematics (e.g., Klieme et al. 2009; Hattie 2009; Helmke 2009), no study has investigated their impact on student competence development in accounting. There is a serious lack of empirical studies not only on the effect of generic didactics but also of different fundamental content-related didactics, such as the widespread "balance-sheet approach", "value flow-focused approach", "function and use-focused approach", and "finance-focused model" (see for example Dolzanski 2014; Plinke 2013; Seifried 2004; Stommel 2014), and (content-related) instructional designs (Helm 2014a, b; Seifried 2004). To the best of our knowledge, Seifried (2004) conducted the only investigation of the effectiveness of 
"value flow-focused approaches", based on a small sample. He found that students taught using this approach did better in problem-solving than those taught using the balancesheet approach. Based on the assumptions of the "three basic dimensions of instructional quality" model we expect that:

H7: Student perception of cognitive activation, classroom management and supportive climate is significantly related to student competency development in accounting, even when controlling for student characteristics such as their cognitive abilities.

Table 1 gives an overview of the theoretical models that underlie our hypotheses. In particular we assume that student cognitive dispositions (e.g., their prior mathematics attainment and previous grades), cognitive learning strategies (e.g., critical reflection of concepts and time management), motivational regulation (derived from self-determination theory, school satisfaction, willingness to make an effort), academic selfconcept and perceived characteristics of their learning environment (e.g., support of basic needs, time spent learning and cognitive activation) are significant predictors of student competence development in the subject Accounting. Two restrictions should

\section{Table 1 Underlying theoretical models and derived hypotheses}

\begin{tabular}{|c|c|}
\hline Theoretical models & Hypotheses derived \\
\hline \multicolumn{2}{|l|}{ Cognitive abilities } \\
\hline $\begin{array}{l}\text { Piaget's theory of cognitive development (1929, } \\
\text { 1970); [Vygotskij's (1978) theory of the zone of } \\
\text { proximal development]; Literacy concept (Winther } \\
\text { 2010) }\end{array}$ & $\begin{array}{l}\text { H1: Students' cognitive abilities, indicated by prior } \\
\text { accounting and maths achievement as well as grades, } \\
\text { reveal as strongest predictor of student competence } \\
\text { development in accounting from grade } 9 \text { through } 11\end{array}$ \\
\hline \multicolumn{2}{|l|}{ Self-concept } \\
\hline Self-enhancement model (Calsyn and Kenny 1977) & $\begin{array}{l}\text { H2: Students' academic self-concept in accounting is } \\
\text { significantly related to students' competency develop- } \\
\text { ment in accounting, even when controlling for stu- } \\
\text { dents' characteristics such as their cognitive abilities }\end{array}$ \\
\hline \multicolumn{2}{|l|}{ Learning strategies } \\
\hline $\begin{array}{l}\text { Self-regulation theory (Schunk and Zimmerman } \\
\text { 2008; Konrad 2008) }\end{array}$ & $\begin{array}{l}\text { H3: Students' use of learning strategies is significantly } \\
\text { related to students' competency development in } \\
\text { accounting, even when controlling for students' char- } \\
\text { acteristics such as their cognitive abilities }\end{array}$ \\
\hline \multicolumn{2}{|l|}{ Motivation } \\
\hline Self-determination theory (Deci and Ryan 1993) & $\begin{array}{l}\text { H4: Students'intrinsic oriented regulation is significantly } \\
\text { related to students' competency development in } \\
\text { accounting, even when controlling for students' char- } \\
\text { acteristics such as their cognitive abilities }\end{array}$ \\
\hline \multicolumn{2}{|l|}{ Gender } \\
\hline None & $\begin{array}{l}\text { H5: Female students develop significantly better than } \\
\text { male students in accounting }\end{array}$ \\
\hline \multicolumn{2}{|l|}{ Economic, social and cultural background } \\
\hline $\begin{array}{l}\text { Human capital theories (Coleman 1988; Bourdieu } \\
\text { 1983) }\end{array}$ & $\begin{array}{l}\text { H6: Students' economical social and cultural status is } \\
\text { significantly related to students' competency develop- } \\
\text { ment in accounting }\end{array}$ \\
\hline \multicolumn{2}{|l|}{ Perception of instructional characteristics } \\
\hline $\begin{array}{l}\text { Basic (deep structure) dimensions of instructional } \\
\text { quality (Klieme et al. 2006) }\end{array}$ & $\begin{array}{l}\text { H7: Students' perception of cognitive activation, class- } \\
\text { room management and supportive climate is signifi- } \\
\text { cantly related to students' competency development } \\
\text { in accounting, even when controlling for students' } \\
\text { characteristics such as their cognitive abilities }\end{array}$ \\
\hline
\end{tabular}


be mentioned here: (1) Although we are aware that factors potentially influencing students' learning might not be linearly and directly related to their academic progress (but may affect it via mediators and interactions), we analysed relatively simple hypotheses including direct effects to avoid overly complex models that cannot be estimated reliably due to the small sample size. (2) Of course other factors are also important to student competency development, such as circle of friends, leisure-time activities (e.g., watching TV has a small negative effect according to Hattie 2009) and learning activities outside school, these could not be included in the present research due to limited resources (e.g., test time).

\section{Methods}

\section{Design and aim of the study and hypotheses}

Our aim was to identify principal determinants of student competence development in accounting with particular focus on the effect of instructional characteristics beyond central student characteristics. As the literature review above has shown, there have been very few attempts to investigate predictors of student academic achievement in accounting. Published studies concentrate on specific aspects (such as learning motivation, Helm 2015, and mathematics attainment, Seeber 2013), work with cross-sectional designs, or investigate relatively small samples. The present study overcomes these shortcomings by referring to prominent theoretical models (such as the model of instructional quality, Klieme et al. 2006) and applying complex linear growth curve models. Furthermore, longitudinal data from 14 commercial upper secondary school classes from grades 9 through 11 measured on four occasions was used. The overall aim was to confirm the hypotheses derived from existing theories and research (see Table 1).

\section{Sample}

To test these hypotheses, we used longitudinal data that allowed examination of longitudinal effects of all the assumed determinants on student accounting competence at different levels. The participants in the LOTUS study were students from BMHS in Austria $\left(74 \%\right.$ girls; $M_{\text {age at to }}=14.4$ years, $\left.S D_{\text {age at t0 }}=0.74\right)$. They completed online questionnaires and competence tests at the beginning of grade 9 and at the end of grades 9,10 and 11, each of which lasted one teaching unit (50 min). Both the competence test and the online questionnaire survey were conducted at school during lessons, in nearly all cases under the supervision of the author of the present paper. This ensured standardized test situations. Participation was voluntary. However, students were encouraged to take part by offering them feedback on the competence test via the platform (http://www.edumetrics. at). In total, 487 students from 14 classes $^{2}$ participated in the study, but sample sizes varied over time due to students dropping out or repeating years-see the attrition analysis below. In a separate teacher questionnaire survey (not included in the present analysis), all 14 Accounting teachers who participated reported that the assignment of teachers to classes did not change in the period investigated. The small number of clusters at the class level limited the number of level 3 predictors that could be included in multivariate

\footnotetext{
2 Three classes (74 students) were from the BMS track and thus had a slightly different curriculum (not with regard to the number of weekly accounting lessons but with regard to learning goals). Thus, separate test versions were developed that take the different learning opportunities into account. Using test linking methods, these test versions were matched to those for BHS students.
} 


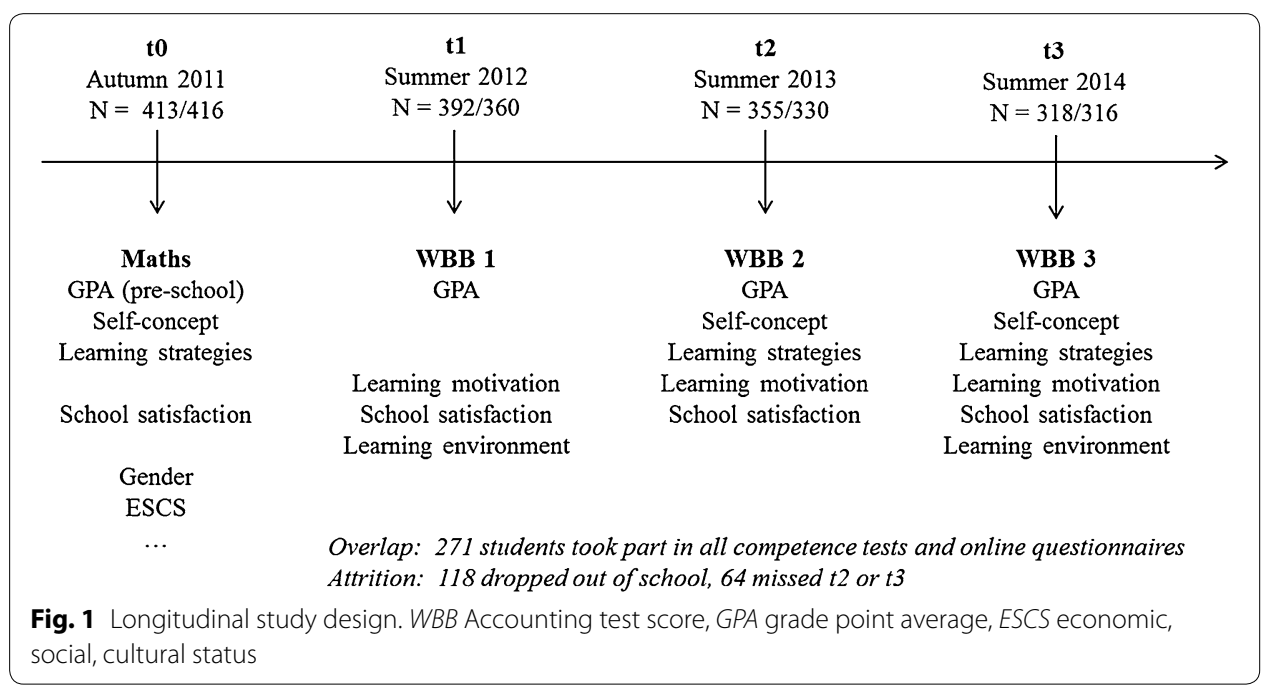

multilevel regressions (see below); however, as Maas and Hox (2005) showed on the basis of simulation studies, multilevel analyses with as few as ten clusters are meaningful as long as the standard errors for the variances at the upper level are not of interest, which was the case in the present study.

\section{Measurements}

Figure 1 presents an overview of the measurements on each of the four occasions (termed waves). Due to limited testing time, it was not possible to assess all the constructs (such as learning environment aspects) in all waves. Table 2 summarises mean values, standard deviations, and Cronbach's alpha at levels 2 and 3 (ICC 2) of the study variables. Correlations among these variables at the time of their first measurement and their retest-correlation are presented in Table 3.

\section{Dependent variable}

\section{Competence development in accounting}

In order to trace student competence development in accounting, the standardized instrument Test of Basic Bookkeeping Knowledge ("Wissensüberprüfung von Basiskenntnissen der Buchhaltung", WBB) was used to assess students at the end of each school year from grade 9 to 11. The WBB was developed by Helm (in press). The students had to complete 53 items in $\mathrm{WBB}_{\mathrm{t} 1}$ and 34 and 30 items in $\mathrm{WBB}_{\mathrm{t} 2}$ and $\mathrm{WBB}_{\mathrm{t} 3}$, respectively, ${ }^{3}$ which essentially required doing book entries of current business transactions in the trade or the hotel and service industry sector (with and without receipts, $\mathrm{WBB}_{\mathrm{t} 1}$ ), and the preparation of changes in bookings and additional entries in line with an annual financial statement $\left(\mathrm{WBB}_{\mathrm{t} 2}\right)$. Additionally, students had to solve tasks from the controlling domain, such as calculating the break-even point or the optimal production program. A sample item is provided below:

\footnotetext{
${ }^{3}$ Since at $t_{2}$ and $t_{3}$ the test forms differed slightly to accommodate differences in school-specific curricula, the number of test items varied slightly.
} 
Table 2 Number of items, scale minimum and maximum, means, standard deviations and internal consistency of the measurements on each occasion

\begin{tabular}{|c|c|c|c|c|c|}
\hline Predictor & $n / \min -\max$ & $\begin{array}{l}\mathrm{t}_{0}(\mathrm{~N}=411) \\
M / S D / \alpha\end{array}$ & $\begin{array}{l}t_{1}(\mathrm{~N}=390) \\
M / S D / \alpha\end{array}$ & $\begin{array}{l}t_{2}(\mathrm{~N}=349) \\
M / S D / \alpha\end{array}$ & $\begin{array}{l}t_{3}(N=318) \\
M / S D / \alpha\end{array}$ \\
\hline \multicolumn{6}{|l|}{ Student cognitive ability } \\
\hline Accounting comp. (wbb) & \multicolumn{2}{|c|}{$\mathrm{t}_{1}: 53, \mathrm{t}_{2-3}: 34 /-\infty$ to $+\infty$} & $-0.44 / 1.14 / 0.91$ & $0.49 / 0.80 / 0.80$ & $0.46 / 1.98 / 0.85^{\mathrm{a}}$ \\
\hline Grades (grades) & $4\left(t_{0}: 3\right) / 1-5$ & 2.87/0.96/0.76 & $2.74 / 0.80 / 0.69$ & $2.89 / 0.81 / 0.75$ & \\
\hline Maths ability (Maths) & $40 / 0-75$ & $51.39 / 10.76 / 0.79$ & & & \\
\hline \multicolumn{6}{|l|}{ Student self-concept } \\
\hline Academic self-concept (asc) & $11 / 1-4$ & $2.37 / 0.45 / 0.80$ & & $2.38 / 0.53 / 0.83$ & $2.43 / 0.51 / 0.83$ \\
\hline \multicolumn{6}{|l|}{ Student learning strategies } \\
\hline Critical understanding (crt) & $4 / 1-6$ & $14.62 / 3.82 / 0.70$ & & $14.21 / 3.78 / 0.65$ & $14.28 / 3.91 / 0.70$ \\
\hline Establishing cognitive (eci) & $4 / 1-6$ & $15.75 / 3.76 / 0.69$ & & $14.98 / 3.82 / 0.61$ & $14.81 / 3.87 / 0.67$ \\
\hline $\begin{array}{l}\text { Summarizing and material } \\
\text { (sas) }\end{array}$ & $4 / 1-6$ & $15.24 / 4.62 / 0.81$ & & $15.38 / 5.13 / 0.84$ & $15.87 / 5.51 / 0.89$ \\
\hline Time management (time) & $4 / 1-6$ & $14.55 / 5.22 / 0.87$ & & $13.06 / 5.37 / 0.86$ & $12.89 / 5.20 / 0.86$ \\
\hline $\begin{array}{l}\text { Social learning support } \\
\text { (socs) }\end{array}$ & $4 / 1-6$ & $15.86 / 3.42 / 0.62$ & & $16.13 / 3.58 / 0.62$ & $16.14 / 3.59 / 0.66$ \\
\hline \multicolumn{6}{|l|}{ Student motivational char. } \\
\hline Intrinsic Regulation (intr) & $5 / 1-5$ & & $2.59 / 1.00 / 0.90$ & 2.46/0.99/0.90 & 2.57/1.03/0.93 \\
\hline Identified Regulation (ident) & $4 / 1-5$ & & $3.70 / 0.95 / 0.85$ & $3.62 / 1.07 / 0.89$ & $3.65 / 1.02 / 0.85$ \\
\hline $\begin{array}{l}\text { Introjected Regulation } \\
\text { (intro) }\end{array}$ & $4 / 1-5$ & & $2.73 / 0.89 / 0.70$ & $2.77 / 0.88 / 0.70$ & 2.83/0.91/0.72 \\
\hline Extrinsic Regulation (extr) & $4 / 1-5$ & & $3.06 / 0.84 / 0.64$ & $3.10 / 0.83 / 0.64$ & $3.02 / 0.78 / 0.59$ \\
\hline School satisfaction (ssat) & $1 / 1-4$ & $3.64 / 0.53 /-$ & $3.23 / 0.71 /-$ & $3.15 / 0.66 /-$ & \\
\hline Willingness for effort (wfeff) & $4 / 1-6$ & $13.53 / 3.59 / 0.68$ & & $12.75 / 3.77 / 0.66$ & $15.44 / 4.31 / 0.72$ \\
\hline \multicolumn{6}{|l|}{ Learning environment char. } \\
\hline $\begin{array}{l}\text { Competence support } \\
\text { (comp) }\end{array}$ & $4 / 1-5$ & & $2.99 / 0.94 / 0.83$ & $3.07 / 0.92 / 0.70$ & $3.27 / 0.92 / 0.78$ \\
\hline Autonomy support (auto) & $5 / 1-5$ & & $3.23 / 0.97 / 0.86$ & $3.26 / 1.00 / 0.86$ & $3.54 / 1.00 / 0.88$ \\
\hline Relatedness support (relat) & $4 / 1-5$ & & $3.15 / 0.81 / 0.78$ & $3.68 / 0.80 / 0.64$ & $3.79 / 0.76 / 0.60$ \\
\hline Structure support (struc) & $8 / 1-5$ & & $3.43 / 0.70 / 0.81$ & $3.58 / 0.78 / 0.85$ & $3.74 / 0.74 / 0.85$ \\
\hline $\begin{array}{l}\text { Classroom management } \\
\text { (tol) }\end{array}$ & $3 / 1-5$ & & 2.99/0.77/0.73 & & $2.63 / 0.86 / 0.69$ \\
\hline Cog. act. (ZPD, coak) & $2 / 1-5$ & & $2.56 / 1.04 / 0.64$ & & $2.57 / 1.03 / 0.74$ \\
\hline $\begin{array}{l}\text { Cog. act. (understanding, } \\
\text { coau) }\end{array}$ & $2 / 1-5$ & & $3.67 / 0.82 / 0.63$ & & $3.49 / 0.85 / 0.75$ \\
\hline $\begin{array}{l}\text { Cog. act. (task analysis, } \\
\text { taska) }\end{array}$ & $3 / 1-5$ & & $3.80 / 0.77 / 0.73$ & & $3.88 / 0.86 / 0.87$ \\
\hline
\end{tabular}

With few exceptions (extr, socs, relat) all constructs show acceptable reliability (around or over the conventional cut-off of 0.70 , italics). For each learning environment feature (at the bottom of the table), ICC 2 (= between-class variance/(betweenclass variance + (within-class variance/mean class size))) was calculated as a measure of reliability at the class level: comp 0.81 , auto 0.86 , relat 0.33 , struc 0.79 , tol. 91 , coak 0.79 , coau 0.61 , taska 0.59

$M$ mean, $S D$ standard deviation

a Due to school-specific curricula, three different test versions had to be constructed for grades 10 and 11 . We report the average Cronbach's alpha. For further information on psychometric features of the WBB see Helm (in press).

You are purchasing trade goods with a total value of EUR 14,500.00 + 20 percent sales tax on credit (3300) for your business. Please, do the book entry and evaluate whether this transaction leads to an increase or decrease in your profits!

\begin{tabular}{|l|l|}
\hline Book entry &,,$+-=$ \\
\hline & \\
& \\
\hline
\end{tabular}


Table 3 Correlations among study variables at the time they were first measured

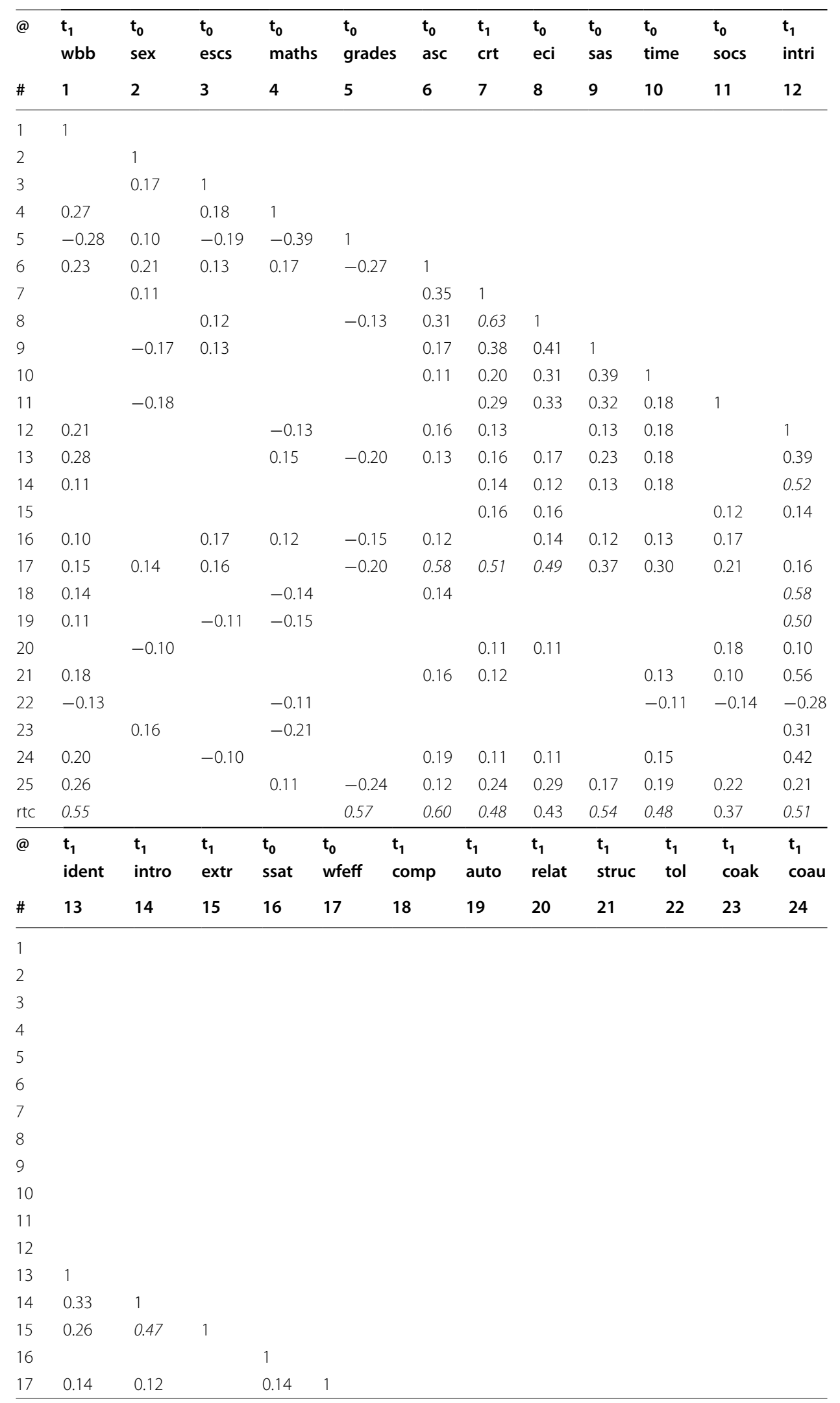


Table 3 continued

\begin{tabular}{lllllllllllll}
\hline$@$ & $\begin{array}{l}\mathbf{t}_{\mathbf{1}} \\
\text { ident }\end{array}$ & $\begin{array}{l}\mathbf{t}_{\mathbf{1}} \\
\text { intro }\end{array}$ & $\begin{array}{l}\mathbf{t}_{\mathbf{1}} \\
\text { extr }\end{array}$ & $\begin{array}{l}\mathbf{t}_{\mathbf{0}} \\
\text { ssat }\end{array}$ & $\begin{array}{l}\mathbf{t}_{\mathbf{0}} \\
\text { wfeff }\end{array}$ & $\begin{array}{l}\mathbf{t}_{\mathbf{1}} \\
\text { comp }\end{array}$ & $\begin{array}{l}\mathbf{t}_{\mathbf{1}} \\
\text { auto }\end{array}$ & $\begin{array}{l}\mathbf{t}_{\mathbf{1}} \\
\text { relat }\end{array}$ & $\begin{array}{l}\mathbf{t}_{\mathbf{1}} \\
\text { struc }\end{array}$ & $\begin{array}{l}\mathbf{t}_{\mathbf{1}} \\
\text { tol }\end{array}$ & $\begin{array}{l}\mathbf{t}_{\mathbf{1}} \\
\text { coak }\end{array}$ & $\begin{array}{l}\mathbf{t}_{\mathbf{1}} \\
\text { coau }\end{array}$ \\
\hline 18 & $\mathbf{1 3}$ & $\mathbf{1 4}$ & $\mathbf{1 5}$ & $\mathbf{1 6}$ & $\mathbf{1 7}$ & $\mathbf{1 8}$ & $\mathbf{1 9}$ & $\mathbf{2 0}$ & $\mathbf{2 1}$ & $\mathbf{2 2}$ & $\mathbf{2 3}$ & $\mathbf{2 4}$ \\
\hline 19 & 0.28 & 0.30 & & & 0.14 & 1 & & & & & & \\
20 & 0.21 & 0.16 & 0.18 & & & 0.17 & 0.16 & 1 & & & \\
21 & 0.46 & 0.31 & 0.15 & & 0.14 & 0.69 & 0.68 & 0.17 & 1 & & & \\
22 & -0.22 & -0.15 & & & & -0.32 & -0.33 & & -0.33 & 1 & & \\
23 & & 0.28 & & & & 0.28 & 0.30 & & 0.23 & & 1 & \\
24 & 0.30 & 0.21 & 0.10 & & & 0.43 & 0.55 & 0.18 & 0.57 & -0.27 & 0.13 & 1 \\
25 & 0.40 & 0.25 & 0.25 & 0.12 & 0.23 & 0.24 & 0.17 & 0.22 & 0.39 & -0.17 & & 0.31 \\
rtc & 0.41 & 0.43 & .38 & 0.32 & 0.37 & 0.31 & 0.18 & 0.34 & 0.26 & 0.38 & 0.31 & 0.31 \\
\hline
\end{tabular}

Only statistically significant $(p \leq 0.05)$ correlations are reported, strong ones in italic. The bottom line shows average re-test correlations ( $\mathrm{rtc}$ ) of the same measurements over time

$w b b$ accounting competence, sex male, escs economic, social, and cultural status, maths maths competence, asc academic self-concept, crt critical understanding, eci establishing cognitive interrelations, sas summarizing and structuring, time time management, socs social learning support, intri, ident, intro, extr intrinsic, identified, introjected and extrinsic motivation, ssat school satisfaction, wfeff willingness to make an effort, comp, auto, relat, struct competence, autonomy, relatedness, and structure support, tol time spent on learning, coak, coau cognitive activation by consideration of student knowledge and offering challenging tasks, 25 = taska performing task analysis

The decreasing number of test items is due to the fact that accounting tasks tend to be more complex in higher grades and thus need more test time (we used vertical scaling methods and anchored items to control for the different test contents, see below). These tasks are derived from the competence model developed by the task force for Austrian vocational educational standards (http://www.bildungsstandards.berufsbildendeschulen.at). This two-dimensional model locates accounting tasks in a content dimension (daily book entries-cost accounting) and in an overlapping behavioural dimension (repetition-development). Furthermore, the test items cover the main content of the competence-oriented curriculum in upper secondary business schools in Austria (BMUKK 2010). In order to obtain the competency values in accordance with the item response theory, (1) student responses were code 1 (correct answer) and 0 (incorrect answer) and (2) marginal and conditional maximum likelihood estimations were performed using the statistical computing software R with the packages "ltm" (Rizopoulos 2006) and „eRm“ (Mair et al. 2011). To transform the various test results to a common metric so that test values can be used interchangeably, vertical scaling methods (based on common item design with 10 anchor items) were used (Kolen and Brennan 2004). As expected, the probability of solving the anchor items correctly increased from $\mathrm{WBB}_{\mathrm{t} 1}$ to $\mathrm{WBB}_{\mathrm{t} 2}$ by 19 percentage points on average, whereas the increase from $\mathrm{WBB}_{\mathrm{t} 2}$ to $\mathrm{WBB}_{\mathrm{t} 3}$ was about eight percentage points on average. According to vertical scaling methods, the item difficulties of $\mathrm{WBB}_{\mathrm{t} 2}$ and $\mathrm{WBB}_{\mathrm{t} 3}$ are adjusted to the scale of $\mathrm{WBB}_{\mathrm{t} 1}$ based on the above-mentioned increase in the difficulty of the anchor items. Since the two dimensions of the theoretical competence model overlap, we assumed one underlying factor that explains the students' response pattern. We thus performed IRT analyses based on the Rasch model. These analyses at both test and item level revealed satisfying reliability (see Helm in press for Rasch model checks at item and test level). Additionally, classical Cronbach's alpha values are reported in Table 2. 
Independent variables

Cognitive abilities

Prior content knowledge Since students possess hardly any domain-specific prior knowledge when they enter school, it was not assessed at time $t_{0}$. However, $\mathrm{WBB}_{\mathrm{t} 1}$ and $\mathrm{WBB}_{\mathrm{t} 2}$ served as prior content knowledge indicators of student development in subsequent years.

Grades Further indicators of student cognitive abilities are their grades, where 1 equals excellent and 5 equals failed. At $\mathrm{t}_{0}$, when students entered BMHS, they were asked to report their final grades in Mathematics, German and English from their previous school (i.e., in most cases general secondary school with three different academic tracks and academic secondary school). In order to make these grades from different academic tracks comparable, we weighted them according to Bacher et al. (2008). At $t_{1}$ through $t_{3}$, grades in Accounting and German were collected from the final report and the last exam. For each measurement wave, the Grade Point Average (GPA) was calculated by averaging the (weighted) grades across subjects. Thus, GPA values range from 1 to 5 (also after weighting).

Mathematics proficiency Since for students of accounting mathematics is an auxiliary discipline, they had to complete a 45 -min mathematics assessment at $\mathrm{t}_{0}$. Proficiency was measured using 40 items from the Trends in International Mathematics and Science Study that reflect Austrian curricula at secondary stage I (Eder et al. 2002). The reliability of the test was satisfying $(\alpha=0.79)$.

\section{Self-concept}

Student academic self-perception was assessed using eleven items from the Austrian study on educational well-being (Eder 1995/2007; e.g., "I learn things quickly"). The items were formulated in a general, subject-independent way. Students were asked to rate these items using a four-point response format ranging from 1 (strongly disagree) to 4 (strongly agree). Again, an index was obtained by averaging all items. See Table 2 for Cronbach's alpha values.

\section{Cognitive learning strategies}

Student learning behaviour was assessed by the so-called LILEST (Linzer Inventar zum Lern- und Studierverhalten/Linzer Inventory for Assessing Study Behaviour; Sageder 1995), which consists of the subscales critical understanding (crt; "When learning something new, I check how this is related to what I already know."), establishing cognitive interrelations (eci; "When learning at home, I try to remember what we did in class."), summarizing and structuring material (sas; "I regularly structure the examination material."), time management (time; "I precisely plan my time for learning.") and social learning support (socs; "I prepare for exams together with classmates"). Each subscale comprises four items with a six-point response format ranging from 1 (never, very seldom) to 6 (very often, always). Indices were built via the sum of each scale, and thus values range from 4 to 24 . See Table 2 for Cronbach's alpha values. 


\section{Motivation}

Motivational regulation In order to record student learning motivation, the German version of the "Academic Self-regulation Questionnaire" (SRQ-A; Ryan and Connell 1989), validated by Müller et al. (2007) was used, which measures four forms of motivational regulation: intrinsic regulation (intri; e.g., I participate in and study accounting because it is fun), regulation through identification (ident; e.g., I participate in and study accounting because it will give me more opportunities in my later career), introjected regulation of behaviour (intro; e.g., I participate in and study accounting because I want the other students to think that I am excellent) and externally regulated behaviour (extr; e.g., I participate in and study accounting to avoid conflicts with my teacher). All scales-with the exception of the first, which comprised five items-had four items which were rated from 1 (strongly disagree) to 5 (strongly agree) and averaged in order to obtain an index for each construct. Cronbach alpha values are reported in Table 2.

Satisfaction with school and willingness to put in effort. In contrast to all other constructs, school satisfaction was measured via a single item (ssat; e.g., "I am satisfied with my school."), which students had to rate using a four-point response format ranging from 1 (very unsatisfied) to 4 (very satisfied). Student willingness to make an effort was measured within LIILEST (see above).

\section{Generic aspects of the learning environment}

Finally, the three basic dimensions of instructional quality (Klieme et al. 2006) were measured via eight constructs, of which three related to perceived cognitive activation in class, one to perceived classroom management, and another four to student perception of a supportive climate. Items were either constructed by the author or derived from the databank published by the German Institute for International Educational Research (DIPF; DaQS, n.d.). All items had a five-point response format ranging from 1 (strongly disagree/very seldom) to 5 (strongly agree/very often), and each construct was built by averaging the corresponding items. See Table 2 for Cronbach's alpha values.

Cognitive activation Two items asked for the students' perception regarding whether their accounting teacher adapts his/her performance expectations and claims to student capability (coak; e.g., "Our accounting teacher asks questions of different levels of difficulty depending on how capable a student is"). Another two items asked for whether learning tasks support knowledge building and understanding (coau; e.g., "In Accounting, we often work on learning tasks that allow us to demonstrate that we have really understood the subject matter"). Finally, we presented three items to the students in order to assess how they deal with learning tasks (taska; "When solving learning tasks/ assignments, I first try to understand what is asked").

Classroom management This broad concept was approximated via one dimension that represents wasteful use of time in class (e.g., "In Accounting, time is often wasted on things that are unrelated to the subject matter").

Supportive climate Since there are no published German language scales for assessing student perceptions of supportive teacher behaviour, we developed appropriate items. Students rated the items on a five-point scale ranging from 1 (strongly disagree) to 5 (strongly agree). 
In the present study, student perception of teacher behaviour that supports autonomy was assessed via five items which primarily measure the teachers' expression of regard for students and the level of autonomy they grant their students, for instance, "Our accounting teacher is able to put him- or herself in our position". Several studies confirmed the kind of teacher behaviour addressed in the items as appropriate for measuring autonomy support (Williams et al. 1996; Deci et al. 1982; Reeve and Jang 2006). Student perception of support of student experiences of competence in lessons was measured via four items in line with the work of Schwarzer and Jerusalem (2002). These items express the degree to which the teacher places importance on the students' (also weak students') ability to achieve learning goals and learning success, for example, "In Accounting, even weak students can be successful". The third SDT dimension, student perception of relatedness support, was assessed using four items to ask whether students learn how to collaborate in class (e.g., "In Accounting, we learn how to help each other in order to gain a better understanding of the materials"). In addition to the three basic needs-related dimensions, a fourth supportive climate dimension, structure-giving teacher behaviour, was included via eight items. In line with Prenzel et al. (2000), these items express-from a student's point of view-how strongly teachers point out the interconnections between different subjects and their relevance to present and future life, and how often they refer to learning task objectives and performance requirements, for instance, "Our accounting teacher explains how the current topic is connected to other subjects".

\section{Economic, social and cultural status}

Student economic social and cultural status (ESCS) was measured in line with the approach suggested by Ehmke and Siegle (2005) using items from the Programme for International Student Assessment (PISA 2006) in order to collect data on three subscales: (1) parents' occupation, (2) parents' education, and (3) domestic property. Based on subscales (1) and (2), the HISEI (Highest International Socio-Economic Index) and the ISCED (International Standard Classification of Education) were coded, respectively. Students' reports on domestic property were Rasch-scaled in order to obtain person parameters. On the basis of these three indices, a latent ESCS factor was calculated whose values represent ESCS values.

\section{Statistical analyses}

All statistical analyses were performed in Mplus (Version 7; Muthén and Muthén 19982014). The coefficients were obtained by means of maximum likelihood estimation with robust standard errors (MLR, i.e., standard errors are robust against violation of the normal distribution assumption). To handle missing data, the full-information maximumlikelihood estimation (FIML) implemented in Mplus was applied. Note that the online questionnaire automatically pointed out omitted items to students, so the problem of missing data arose mainly in the competence tests and due to panel attrition.

\section{Attrition analyses}

Attrition analyses were conducted to determine if those students participating in all four waves $(\mathrm{n}=271, \# 1)$ differed on the measurements in wave 1 and 4 respectively from (1) 
those apparently dropping out of school $(\mathrm{n}=118, \# 2),(2)$ those apparently repeating a class $(\mathrm{n}=34, \# 3)$ and (3) those not participating in either wave 2 or $3(\mathrm{n}=64, \# 4)$.

As expected, those students who participated in all four waves initially showed higher mathematics skills $(F(2,410)=8.741, p=0.00$; Scheffé \#1-\#2 $p=0.00)$, better grades from previous schools $\left(F(2,408)=6.294, p=0.00\right.$; Scheffé $\left._{\# 1-\# 2} p=0.00\right)$ and higher school satisfaction $\left(F(2,408)=4.108, p=0.02\right.$; Scheffé $\left._{\# 1-\# 2} p=0.02\right)$ than school drop-outs. In addition, after one year of upper secondary schooling, they scored higher on identified and introjected regulation than school drop-outs $(F(2,358)=7.048, p=0.00$; Scheffé $_{\# 1-\# 2} p=0.00 ; F(2,358)=4.297, p=0.02$; Scheffé $\left._{\# 1-\# 2} p=0.02\right)$. This is in line with the assumption that on the one hand students share or even have integrated educational values (of accounting instruction) and on the other that they "are at peace with themselves" and wish to avoid, for example, guilt or anxiety. Finally, students taking part in all waves reported that they perform task analysis more often than both other groups $\left[\left(F(2,373)=9.589, p=0.02\right.\right.$; Scheffé \#1-\#2 $p=0.00$, Scheffé $\left._{\# 1-\# 4} p=0.02\right]$, which indicates more frequent use of a meaningful and successful method of completing tasks in accounting.

An analysis of how repeaters (students from upper grades who joined the study at later waves) differ from others in wave four showed that, as expected, they reported marginally lower competence scores in accounting and less willingness to make an effort $(F(2$, $315)=4.060, p=0.02$; Scheffé \#1-\#3 $p=0.03$ ), and perceived less competence support $(F(2,314)=3.383, p=0.04$; Scheffé \#1-\#3 $p=0.04)$.

To summarise, as expected, students who participated continuously throughout all four waves showed on average more preferable characteristics than those who dropped out of the panel, joined at later waves due to repeating a school year or missed a whole wave. Since these findings stem from classroom research on natural settings they represent common selection effects of commercial upper secondary schools and thus are a characteristic of the validity of the findings. The following results were interpreted against this background.

\section{Taxonomy of models and centring}

In order to identify determinants of student competence development in accountingmore precisely, their initial status (intercept) and growth (slope) -a series of three-level models involving repeated measurements of student competence in accounting as outcome and time-varying predictors at the within-student level (level 1), time-invariant predictors at the between-student level (level 2) and context effects at the between-class level (level 3) was estimated. At level 1 we were looking for associations between changes in student scores across the three measurements and changes in the time-varying predictors. At levels 2 and 3, we were looking for student and class characteristics that predict the initial status and growth of student competence in Accounting at levels 2 and 3.

To handle the vast number of determinants derived from the literature, a two-step approach as suggested by Singer and Willett (2003) was used: First, each predictor was included separately in a simple conditional model to test its association with the initial status and growth at different levels of the model. Second, we included all predictors that turned out to be significant in step 1 in a single full conditional model to determine whether particular predictors, such as context variables, remained relevant when 
student characteristics, such as their cognitive abilities, were controlled for. However, for the following two reasons, a series of full conditional models was estimated:

1. Estimating effects of level 3 variables. The small number of clusters at level 3 (class level, $\mathrm{N}=14$ ) limited the number of predictors included. Thus, for each context effect of interest, we ran a separate model that included all level 1 and 2 predictors, but only the level 3 predictor of interest and the class mean mathematics ability score in order to control for its context effect. All variables were centred around the grand mean, as recommended by Brincks (2012) and Enders and Tofighi (2007).

2. Estimating effects of level 1 and 2 variables. In multilevel analysis, centring predictors is particularly important since parameter interpretation depends heavily on the centring method chosen: using the group mean (cwc) or the grand mean (cgm). In accordance with the work of Brincks (2012; see also Enders and Tofighi 2007), researchers should use cgm when the effects of a variable at all three levels are of interest. However, as mentioned above, it was not possible to model all predictors at all three levels. Thus, separate models were used for level 1 and level 2 variables, but they contained all predictors at levels 1 and 2 and aggregated mathematics and grade scores at level 3. However, in the first model, all level 1 variables were centred around the group mean, and their corresponding level 2 aggregate was included at level 2, as recommended by Ntoumanis (2014), in order to obtain pure estimates of effects of within-student variables. In the second model, in order to identify effects of level 2 predictors that are controlled for by level 1 and level 3 equivalents, centring was achieved as follows: To all level 2 predictors that had no equivalent at level 3, cwc was applied, and cgm was applied to the rest.

Finally, time (values $=1,2$ and 3) was centred around 1, since we were interested in predicting student initial accounting competence at the end of grade 9 (Biesanz et al. 2004). All variables were $\mathrm{z}$-standardised in order to obtain comparable estimates.

Prior to the simple and full conditional models, unconditional means and unconditional growth models were estimated in order to investigate the amount of variation in competence development at the three different levels. Thus, the taxonomy of models presented in this paper is as follows: (1) unconditional models, (2) simple conditional models and (3) full conditional models. These models were evaluated using pseudo $R^{2}$, as recommended by Singer and Willett (2003) and Snijders and Bosker (2000), and using the Akaike and Bayesian Information Criteria (AIC, BIC).

\section{Evaluating model assumptions}

To determine to what extent the model's assumptions were met, we checked the functional form of individual changes, normality and homoscedasticity of residuals at all three levels of the models using the statistical software MLwiN (Version 2.10; Rasbash et al. 2009). Customised graphs implemented in MLwiN allowed us to plot normal score plots and catch-all plots in order to investigate the properties of the residuals. The figures in the appendix show that residuals at level 2 and 3 follow a normal distribution and are within the acceptable interval of three standard deviations above and below the mean. Furthermore, investigation of individual change trajectories of WBB scores over 
the three measurements showed that time is related to the WBB score with $r=0.50$ at a minimum for exactly $75 \%$ of the students. Although $19 \%$ of the participants showed a negative association-which indicates that their competence development was negative-these figures support the argument of linearity.

\section{Results and discussion}

\section{Descriptive statistics}

Due to space limitations, Table 3 presents only correlations among the study variables at the time they were first measured. As predicted, accounting competence in $t_{1}$ is moderately but statistically significantly associated with student mathematics ability, grades, self-concept, intrinsic and identified motivation, and their perceptions of characteristics of the learning environment such as teacher support of basic needs, structure and cognitive activation. As the values at the bottom of Table 3 show, cognitive variables and self-concept, some learning strategies, and intrinsic motivation remain most stable over time. In contrast, perception of teacher behaviour seems to be least stable.

\section{Bivariate linear growth curve models}

In the following section, we first report findings from bivariate linear growth curve models along the three levels of the hierarchical structure of the data. Then we interpret and link the results to theory and hypothesis.

Level 1 in Tables 4 and 5 represents the within-student (intra-individual) level, and refers to the effect of change in a predictor over the three measurements on those parts of student accounting test scores at the three different measurement occasions which deviate from the overall-time student score and the overall class score a student belongs to. In other words, they represent within-person association between a predictor (e.g., intrinsic motivation) and accounting competence over time, after partialling out between-person and between-class differences in the predictor. As the results show, there are hardly any time-varying variables that significantly predict (partial) student competence development at level 1 . Only student perception of support of basic psychological needs and structure proved significant, though small. Critical thinking as a learning strategy is, against all expectations, negatively associated with (partial) student competence development at level 1 . However, the effect is very small and ignorable.

Level 2 of Tables 4 and 5 comprises two different effects of interest: first, the (betweenperson) effect of a predictor (averaged at the student level) on student initial status in accounting competence (at measurement 1); and second, the (between-person) effect of a predictor (averaged at the student level) on between-student growth in accounting competence (in grades 9, 10 and 11), controlled for inter-class predictor differences. The results indicate that significant effects can only be observed for student initial status. As expected, initial status is positively predicted by student cognitive abilities, academic self-concept, learning motivation, and perception of supportive teacher behaviour and cognitive activation in class. Again, and in line with our assumptions, cognitive abilities have the highest impact, whereas perception of competence support in class negatively predicts (against all expectations) initial status. One has to keep in mind that inter-class differences are partialled out; hence, it is the predictors' deviations from the class mean 


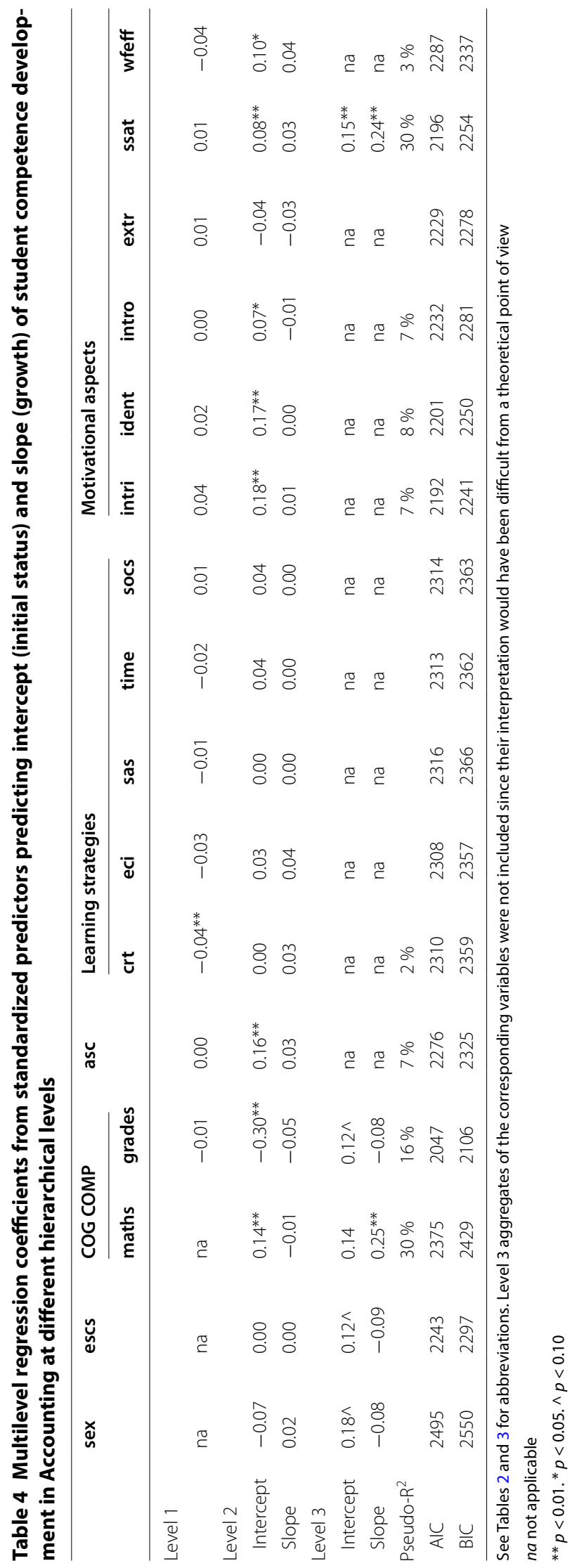


Table 5 Multilevel regression coefficients from standardized predictors predicting intercept (initial status) and slope (growth) of student competence development in Accounting at different hierarchical levels

\begin{tabular}{|c|c|c|c|c|c|c|c|c|}
\hline & \multicolumn{4}{|c|}{ Supportive climate } & \multirow{2}{*}{$\begin{array}{l}\mathrm{CM} \\
\text { tol }\end{array}$} & \multicolumn{3}{|c|}{ COACTIV } \\
\hline & comp & auto & relat & struc & & coak & coau & taska \\
\hline \multicolumn{9}{|l|}{ Level 1} \\
\hline & $0.07^{* *}$ & $0.08^{*}$ & $0.06^{*}$ & $0.07^{* *}$ & -0.03 & 0.04 & 0.02 & 0.00 \\
\hline \multicolumn{9}{|l|}{ Level 2} \\
\hline Intercept & $-0.14^{* *}$ & $0.15^{* *}$ & $0.14^{* *}$ & $0.17^{* *}$ & -0.08 & -0.01 & $0.15^{* *}$ & $0.17^{* *}$ \\
\hline Slope & 0.00 & 0.00 & -0.01 & -0.01 & 0.00 & 0.00 & 0.00 & -0.01 \\
\hline \multicolumn{9}{|l|}{ Level 3} \\
\hline Intercept & -0.11 & -0.13 & -0.09 & -0.02 & -0.05 & $-0.15^{*}$ & -0.07 & $0.20^{* *}$ \\
\hline Slope & $-0.24^{*}$ & $-0.22^{*}$ & -0.05 & -0.08 & -0.09 & $-0.20^{* *}$ & 0.15 & $0.17^{* *}$ \\
\hline Pseudo- $R^{2}$ & $14 \%$ & $12 \%$ & $4 \%$ & $4 \%$ & & $18 \%$ & $9 \%$ & $30 \%$ \\
\hline $\mathrm{AIC}$ & 2266 & 2270 & 2264 & 2263 & 1194 & 1434 & 1414 & 1383 \\
\hline $\mathrm{BIC}$ & 2325 & 2329 & 2323 & 2322 & 1246 & 1488 & 1468 & 1437 \\
\hline
\end{tabular}

See Table 3

that affect student initial status. For example, when a student scores high on intrinsic motivation compared to the average of the class, he/she also has a higher initial status.

Effects of a predictor on the initial status and growth can also be observed at Level 3, but in this case it is the class mean of a predictor that correlates with the initial status and growth of an entire school class. With regard to the initial status, the class-average of school satisfaction, cognitive activation (sensu responding to level of student ability), and task analysis were identified as significant determinants. At an error probability of $p<0.10$, class mean of previous school year GPA, class mean of economic, social and cultural status, and the proportion of boys in a class positively correlate with the initial status of the class. Growth at the class level is positively predicted by the class mean in mathematics competence and task analysis, and negatively correlated with student aggregated perception of competency, autonomy support, and cognitive activation (sensu responding to student ability level). These negative correlations are clearly against our expectations.

When looking at the measures of model fit (pseudo $\mathrm{R}^{2}$, AIC, and BIC), mathematics, school satisfaction and task analysis explain most of the variation in student competence development. Referring back to our hypotheses, the results from the bivariate, linear growth curve modelling clearly confirm the associations assumed in hypotheses 1 (cognitive abilities: $b_{\text {level } 2}^{*}=0.14^{*},-0.30^{* * *} ; b_{\text {level } 3}^{*}=0.14^{* *} / 0.25^{* * *}$ ), 2 (academic selfconcept: $b_{\text {level } 2}^{*}=0.16^{* * *}$ ) and 4 (motivational aspects: $b_{\text {level } 2}^{*}=0.07^{*}-0.18^{* *}, b_{\text {level } 3}^{*}$ $\left.=0.15^{* * *} / 0.24^{* *}\right)$, however they only partially confirm 7 (dimension of instructional quality: $\left.b_{\text {level } 1}^{*}=0.06^{*}-0.08^{*} ; b_{\text {level } 2}^{*}=-0.14^{* * *}-0.17^{* * *}, b_{\text {level } 3}^{*}=-0.24^{* * *}-0.20^{* *}\right)$. The rest of the expected effects were revealed to be insignificant.

Interpretation and link to theory In accordance with our research question, we concentrated most on the effects of the three basic dimensions of instructional quality: Klieme et al. (2006) assume that cognitive activation reflects elaborative student learning and thus leads to higher achievements. Bivariate analysis confirms this hypothesis with regard to the two cognitive activation dimensions "understanding" and "task analysis": 
challenging learning tasks and reflecting about learning tasks before working them out indeed predict student competence (development) in accounting. However, the opposite is true for cognitive activation in the sense of adapting teachers' expectations and the difficulty of questions to the students' abilities. To avoid redundancies, reasons for this negative association at the class level are reported in the section "multivariate linear growth curve models". The second basic dimension-classroom management-is assumed to lead to an increase in learning time, which should in turn be positively associated with achievement. The positive effect of time spent on learning was not confirmed. Again, the interpretation follows in the next section. Supportive climate, the third basic dimension, is assumed to lead to higher intrinsic motivation, which in turn predicts student academic achievement. Although we did not test for the mediation effect, the assumption that the four dimensions of a supportive climate (competence, autonomy, relatedness, structure) positively predict student competence in accounting was confirmed at levels 1 and 2 with two exceptions: both competence and autonomy support showed a negative effect at level 3 and competence support allone at level 2. We interpret this contradiction as follows: when teachers try to improve low-performing students and provide them with feelings of success and autonomy, it may slow down the average class progress and/ or instructions might not be sufficiently challenging.

With regard to generic student characteristics, using the self-enhancement, self-regulation and self-determination theories, we hypothesized that student self-concept, learning strategies, and intrinsic motivation positively predict student competence development in accounting. With the exception of the effect of learning strategies, we could indeed corroborate these assumptions:

- Self-enhancement model According to our data, student self-concept positively predicts student initial competence, which confirms that a positive self-concept is a preferable precondition for student engagement, which in turn leads to higher achievement [see the correlation between self-concept and willingness for effort (wfeff) and the positive effect of wfeff on student development].

- Self-determination theory It is assumed that learning takes place when positive emotions are involved. Since intrinsic motivation is more strongly related to positive emotions (driven by the feeling of autonomy), we hypothesized that intrinsic oriented forms of motivation are stronger predictors of student performance than extrinsic forms. The decreasing regression coefficients confirm these assumptions. In accounting, intrinsic and identified motivations are obviously emotionally loaded, positive drivers of academic success. Furthermore, as expected, student satisfaction with school is also positively related to student competence development.

- Self-regulation theory The hypothesis that students who apply learning strategies more often might use more appropriate strategies of learning, as argued by selfregulation theorists, was not confirmed. Again, explanations for these missing effects are given below.

With regard to gender and ESCS, no effects were observed (see below for explanations). According to the literacy concept and the theory of cognitive development, it was assumed that students with greater prior attainment in maths and better grades in 
previous school years perform better since (1) they possess more auxiliary mathematical knowledge needed for accounting and (2) they are more capable when it comes to integrating new accounting concepts into existing schemata. The positive effects of maths and grades support these assumptions.

In order to identify determinants of academic achievement in a multivariate way, only those predictors that were significant in the previous analysis were included in the model. Given the small number of clusters at level 3 (14 classes), this selection seems justified both theoretically and empirically (Singer and Willett 2003, p. 107).

\section{Multivariate linear growth curve models}

Following convention (Singer and Willett 2003), we first report results from fitting an unconditional means model and an unconditional growth model to the data. Second, results from the series of multivariate models given in Table 6 are presented.

The unconditional means model is not about analysing change, but partitions the total variation in competence development (random effects) in a meaningful way and gives the overall mean (fixed effect). Estimates for random effects showed that 62,8 and $30 \%$ of variance (the last two numbers represent the ICC at the corresponding level) occur at within-student, student and class levels, respectively, which indicates that the average degree of accounting competence clearly varies most over time and across classes. In comparison, (between-student) variations in student deviations from the class average were limited, albeit significant. Finally, the fixed effect estimate gives the grand mean across all measurement waves, students and classes, and shows that the average competence equals 0 , which is in line with the IRT-based WBB scale.

The unconditional growth model adds time as a single time-varying within-student level predictor of student competence development. The fixed effect estimate for the slope indicates that time is substantially related to the outcome variable: the slope is $b^{*}=0.47(S E=0.16)$ and thus higher than those of any other predictors presented in Tables 4 and 5 . The grand mean (intercept), referred to here as initial status, decreases to $b^{*}=-0.33$, which indicates that at $\mathrm{t}_{1}$ students performed slightly-but statistically significantly-below the theoretical mean of 0 . Random effects are of particular interest. The within-person variance $\left(\sigma_{\varepsilon}^{2}=0.77, S E=0.13\right)$ indicates that students scattered substantially around their individual linear change trajectories. Whereas the variation at student level is insignificant (initial status and growth deviation from the class mean does not vary much; $\sigma_{0}^{2}=0.22, S E=0.18, \sigma_{1}^{2}=0.05, S E=0.09$ ), initial status and growth vary significantly across classes $\left(\sigma_{0}^{2}=0.20, S E=0.09 ; \sigma_{1}^{2}=0.33, S E=0.10\right)$. This indicates that student development differed significantly across the three measurement waves; however, the most substantial contribution is attributable to the class level. Furthermore, random effects show that initial status and growth do not correlate significantly, neither at the between-student level $\left(\sigma_{01}=0.03, S E=0.11\right)$ nor at the class level $\left(\sigma_{01}=0.09, S E=0.07\right)$. These results answer two key questions: First, since there is no significant variation at level 2 , it might be difficult to identify predictors at that level. Second, the missing covariance between initial status and growth in accounting competence at both levels 2 and 3 indicates that neither "fanning in" nor "fanning out" (i.e., the so-called Matthew effect) patterns are observable. Thus, the implicit hypothesis that students or classes that perform better at $t_{1}$ also show significantly better development was 
Table 6 Full conditional models of competence development in Accounting

\begin{tabular}{|c|c|c|c|c|c|c|c|c|c|c|c|c|c|}
\hline \multirow[t]{3}{*}{$\begin{array}{l}\text { Fixed } \\
\text { Effects }\end{array}$} & \multicolumn{2}{|c|}{$\begin{array}{l}\text { Level } 1 \\
\text { (within- } \\
\text { student) }\end{array}$} & \multicolumn{4}{|c|}{ Level 2 (between-student) } & \multicolumn{4}{|c|}{ Level 3 (between-class) } & \multirow{3}{*}{$\begin{array}{l}\mathbf{R}^{2} \\
\%\end{array}$} & \multirow{3}{*}{ AIC } & \multirow{3}{*}{ BIC } \\
\hline & \multirow[t]{2}{*}{ Est. } & \multirow[t]{2}{*}{$p$} & \multicolumn{2}{|c|}{$\begin{array}{l}\text { Predicting } \\
\text { initial status }\end{array}$} & \multicolumn{2}{|c|}{$\begin{array}{l}\text { Predicting } \\
\text { growth }\end{array}$} & \multicolumn{2}{|c|}{$\begin{array}{l}\text { Predicting } \\
\text { initial status }\end{array}$} & \multicolumn{2}{|c|}{$\begin{array}{l}\text { Predicting } \\
\text { growth }\end{array}$} & & & \\
\hline & & & & $p$ & & $p$ & & $p$ & Est. & $p$ & & & \\
\hline M1: maths & & na & & 0.032 & -0.05 & 0.134 & & 0.000 & 0.34 & 0.001 & 39 & 1091 & 1294 \\
\hline M2: grades & 0.00 & 0.917 & -0.28 & 0.000 & -0.05 & 0.128 & -0.40 & 0.001 & -0.16 & 0.028 & 48 & 1085 & 1296 \\
\hline M3: asc & -0.02 & 0.634 & 0.04 & 0.458 & 0.02 & 0.647 & 0.11 & 0.461 & -0.02 & 0.727 & 39 & 1095 & 1306 \\
\hline & & & & & & & & & & 0.543 & 43 & 1093 & 1305 \\
\hline M5: intri & 0.01 & 0.809 & 0.11 & 0.047 & -0.03 & 0.509 & 0.09 & 0.681 & -0.05 & 0.750 & 39 & 1095 & 1306 \\
\hline M6: wfeff & 0.01 & 0.855 & -0.01 & 0.692 & -0.03 & 0.413 & 0.09 & 0.431 & -0.02 & 0.737 & 39 & 1094 & 1305 \\
\hline M7: comp & 0.07 & 0.027 & -0.06 & 0.431 & 0.01 & 0.744 & 0.32 & 0.138 & 0.00 & 0.988 & 40 & 1094 & 1305 \\
\hline M8: auto & -0.02 & 0.625 & 0.05 & 0.418 & 0.01 & 0.714 & $\underline{0.27}$ & $\underline{0.089}$ & 0.02 & 0.899 & 40 & 1094 & 1305 \\
\hline M9: relat & 0.05 & 0.191 & -0.01 & 0.783 & 0.02 & 0.426 & -0.01 & 0.965 & 0.05 & 0.624 & 39 & 1095 & 1306 \\
\hline M10: struc & -0.04 & 0.270 & 0.05 & 0.432 & -0.03 & 0.369 & 0.35 & 0.000 & 0.12 & 0.036 & 47 & 1087 & 1298 \\
\hline M11: coak & $\underline{0.04}$ & $\underline{0.087}$ & -0.08 & 0.051 & 0.03 & 0.261 & -0.03 & 0.854 & 0.01 & 0.937 & 39 & 1095 & 1307 \\
\hline M12: coau & 0.02 & 0.402 & -0.07 & $\underline{0.079}$ & -0.01 & 0.727 & 0.41 & 0.000 & 0.25 & 0.000 & 39 & 1067 & 1279 \\
\hline M13: taska & -0.03 & 0.389 & 0.08 & 0.226 & -0.01 & 0.775 & $\underline{0.31}$ & $\underline{0.060}$ & $\underline{0.10}$ & $\underline{0.059}$ & 49 & 1085 & 1296 \\
\hline
\end{tabular}

Levels 1, 2, and 3 comprise time-varying predictors, time-invariant student variables and context effects, respectively. All models M1 to M2 include all level 1 and level 2 models, but only the class mean in mathematics and the class mean of the variable indicated in the model's name. Italic values indicate significant at a level of $5 \%$ error probability. Underlined italic values indicate significant at a level of $10 \%$ error probability. Pseudo $\mathrm{R}^{2}$ was calculated according to Singer and Willett (2003) by taking the square of the correlation between the observed WBB and the predicted WBB. Prediction was based on fixed effects only. See Table 2 for abbreviations

not confirmed. Finally, model fits show that $41 \%$ of the within-person variation in competence is systematically associated with time. However, the pseudo $\mathrm{R}^{2}$ was only $7 \%$, indicating that the unconditional growth model without predictors explains little of the variation in the dependent variable.

The series of full conditional models tests for the hypothesized effects when investigated simultaneously and controlling for principal student characteristics. As in the bivariate analysis section, we first report our final empirical findings along the three levels of the hierarchical structure of the data before interpreting and linking them to the underlying theoretical predictions.

At the within-student level, the perception of competence support being offered by teachers remained as a positively correlated predictor. More precisely, it is the student deviation from the perceived teacher support averaged over the three measurement waves that predicts student competence development in accounting when inter-person effects and context effects of a class' average cognitive ability are controlled for. In fact, increased competence support increases competence development in accounting. Perception of support of other basic psychological needs is no longer positively associated with student academic performance in accounting. With an error probability of $p=0.09$, cognitive activation (sensu responding to students' ability level) also exhibits predictive power $\left(b^{*}=0.04\right)$. Again, an increase in perceived cognitive activation over the first 3 years of commercial upper secondary school leads to improved student performance.

At the between-student level, in addition to student cognitive abilities (mathematics ability, previous grades), intrinsic motivation is positively correlated with initial status 
of competence. Again, the correct interpretation is that it is actually a student's relative standing in class in terms of mathematics ability, previous grades and intrinsic motivation that is correlated with the initial status: Students who reported scores that are higher than their class average had higher initial statuses. The opposite is true for cognitive activation (sensu responding to students' ability level): students with a lower initial accounting competence more often reported (relative to their class average), for example, that their accounting teacher adapts the difficulty of questions to student abilities. With an error probability of $p=0.08$, the same applies to cognitive activation (understanding). No predictors of student growth were identified at level 2 (between-students growth). One reason might be the low variation at that level of the model. This indicates overall that, when initial status and levels 1 (time-varying predictors) and 3 (school class affiliation and context) are controlled for, students develop similarly.

At the between-class level, the models show context effects for class-level variables such as the class mean of student mathematics ability at the beginning of grade 9 . The average "mathematics ability" of a class exhibits a substantial context effect on both student initial status and development of accounting skills. Likewise, in addition to the context effect of mathematics, grades from the previous school year, teacher structural support and cognitive activation (understanding) in accounting lessons, and the class mean of analyzing/thinking about learning tasks before attacking them also has context effects (when controlling for level 1 and level 2 predictors). Furthermore, the average satisfaction with school of a class and teacher support of autonomy in accounting are, with an error probability of $p<0.10$, positively associated with a class' initial competence, again when level 1 and 2 predictors are controlled for.

Measures of model fit for the multivariate three-level linear growth models show that the best fit of the data is achieved by modelling context effects of mathematics, grade, structure and task analysis. This indicates that, in addition to time and student variables, the composition of the class in terms of capable students and the cognitive activation provided in accounting lessons are important for predicting student competence growth in accounting. Referring back to our hypotheses, the results from multivariate linear growth curve modelling again clearly support the associations assumed in hypotheses 1 (cognitive abilities: $b_{\text {level } 2}^{*}=0.09^{*} /-0.28^{* * *} ; b_{\text {level } 3}^{*}=0.57^{* * *} / 0.34^{* * *} /-0.40^{* * *} /-0.16^{* *}$ ) and 4 (motivational aspects: $b_{\text {level } 1}^{*}=0.07^{*} ; b_{\text {level } 2}^{*}=0.11^{*}$ ) and partially confirm hypothesis 7 (dimension of instructional quality: $b^{*}{ }_{\text {level } 2}=-0.08^{*} ; b^{*}{ }_{\text {level } 3}=-0.12^{*}$ to $0.41^{* * *}$ ). The remaining expected effects were revealed to be insignificant.

Interpretation and link to theory In the full conditional models, several hypothesized determinants proved to be insignificant predictors when included in multivariate analysis: self-concept, use of learning strategies, classroom management, gender, and ESCS. This is against our expectations, since we hypothesized on the basis of different models (self-enhancement theory, self-regulation theory, basic dimension model of instructional quality, capital theories) that these factors should be positively related to student competence development even after controlling for student characteristics (e.g., cognitive abilities). Although the academic self-concept is positively related to accounting competence in the bivariate analysis, this effect vanishes when controlling for other student characteristics. One explanation might be the missing mediator "student learning effort". As hypothesized by the self-enhancement model, student self-concept is the main driver of students' 
willingness to make learning efforts-see the correlation analysis $(r=0.58)$. As reported in the bivariate analysis, effort in turn predicts student competence. Thus, there might be an indirect rather than a direct effect of self-concept. With regard to the missing effect of learning strategies used, we must concede that the operationalization might not be sufficiently suitable to reveal significant effects. The frequency of use of learning strategies such as critical understanding, establishing cognitive interrelations, summarizing and structuring material, and social learning support might not be predictive of student progress in a subject that focuses on repetitive learning (Götzl et al. 2013) "instead of understanding". In line with this, self-regulation experts argue that learning tasks need to be sufficiently challenging in order to force students to apply (meta-) cognitive learning strategies (Mandl and Fischer 1982; Schiefele and Pekrun 1996). Again, the repetitive learning character of accounting and the dominance of low-level learning tasks (Haselgruber 2015) might not accord with this claim. Furthermore, the learning strategies we assessed are more often used in "knowledge-centered subjects", such as Geography and Business, where extensive textual material must be mastered, as opposed to rules, laws and algorithms in subjects such as Mathematics and Accounting. The expected competence gap with regard to gender was not observed, maybe because the majority of the boys attended HAK, which has a slightly more intensive accounting curriculum than the girl-dominated HLW; this more intensive curriculum might compensate for the gap. The missing effect of ESCS does not contradict capital theories; since the sample under investigation went through social selection processes after grades 4 (primary to secondary stage 1 ) and 8 (secondary stage 1 to stage 2), it represents a relatively homogeneous group with regard to ESCS. Additionally, as Hattie (2009) argued, social background effects are stronger in the early school career.

Despite these contradictive findings, the remaining hypothesized predictors were revealed to be significant ones. Table 6 shows that generic aspects of the learning environment (cognitive activation, and supportive climate) determine student competency development in Accounting when controlling for the effects of key student characteristics, such as their prior attainment in Accounting and Maths and their motivational regulation. Thus, in summary, the following theoretical assumptions were confirmed:

(1) The three basic dimensions of instructional quality model assumes that when students are cognitively engaged-in the sense of doing (co-)constructive and reflective higher-level thinking and developing elaborate, content-related knowledge-they perform better. The positive effect of cognitive activation in the sense of providing students with learning tasks that challenge their understanding of the topic supports this assumption, at least at the class level. However, at the individual level, perception of individualization with regard to prior knowledge revealed negative effects. An explanation for this contradictory finding lies in the reversed causality assumption: teachers apply this kind of individualizing strategy (adapting expectations and the difficulty of questions to their students' abilities) more often to poorly performing students in a class as a remedial tool, whereas capable students less often experience individual support. Another explanation might be that this finding indicates that teachers more often temper their expectations of poorly performing students, and thus they might challenge these students less frequently to engage in higher-level thinking, etc. 
(2) Beyond cognitive activation, the model assumes that "clear, well-structured, adaptive classroom management is a precondition for time-on-task engagement of students, and thus has a positive impact on cognitive achievement and understanding of content" (Klieme et al. 2009, p. 141). The postulated assumption that a clear structure determines student competence development in mathematics was also confirmed in the present study for the domain of accounting. Surprisingly, time spent on learning-which was found to be an important predictor in many other studies-was not significantly related to student competence development at any hierarchical level of the data analysis. However, in the descriptive analysis, waste of time was significantly negatively related to student competence in grade $9(\mathrm{r}=-0.13)$ and even more strongly in grade $11(\mathrm{r}=-0.29)$. Thus, although not significant in the growth modelling approach, the data clearly shows that efficient use of time is also related to student success in accounting.

(3) In accordance with the self-determination theory, the model in (1) postulates that teachers' support of psychological basic needs affects student motivation, which in turn affects academic performance. Although we did not model this mediation effect, our analyses show that both competence support and intrinsic motivation are related to student competence development in accounting. Furthermore, extrinsic motivation-as hypothesized by the self-determination theory-is not related to competence development in accounting.

(4) (1-3) represent positive answers to our research question, since the above-mentioned learning environment characteristics reveal significant effects, even after controlling for student characteristics such as their cognitive abilities. The positive effects of students' previous school year grades and prior attainment in mathematics and accounting support Piaget's theory of cognitive development and the literacy concept (Winther 2010). The first theory assumes that students with greater prior knowledge are more capable of integrating new knowledge into existing schemata. The positive effects of grades and the high correlations among the three accountancy test scores (around $r=0.50-0.60$ ) indicate that those having greater prior knowledge develop better. The literacy concept further argues that mathematics is an auxiliary competence that supports knowledge acquisition in accounting, since several procedures are applied also in accounting (e.g., doing calculations) or are at least similar (e.g., logical thinking). Thus, it is hardly surprising that there is a strong effect of prior mathematics attainment on student competence development in accounting.

\section{Conclusion}

The lack of research into predictors of student learning success in accounting prompted us to investigate determinants of student competence growth in this subject. Referring to prominent theoretical models used in educational research, such as the "three basic dimensions of instructional quality" (Klieme et al. 2006), the self-enhancement model (Calsyn and Kenny 1977), the self-regulation theory (Schunk and Zimmerman 2008), the self-determination theory (Deci and Ryan 1993), capital theories (Coleman 1988; Bourdieu 1983) and Piaget's theory of cognitive development (1929, 1970), we selected potential determinants of student competence development in accounting. In particular, 
our aim was to show to what extent the three basic dimensions of instructional quality (cognitive activation, classroom management and supportive climate) determine student competency development in accounting, controlling for the effects of key student characteristics such as their prior attainment in accounting and mathematics, self-concept, learning strategies, motivational regulation, and socioeconomic status. By means of multilevel models and repeated measurements, we analysed data from 487 students from commercial upper secondary schools in grades 9 through 11.

The results from the bivariate and multivariate analyses taken together confirm our hypotheses 1, 2, 4 and 7 (with the exception of cognitive activation in the sense of individualization and classroom management). Moreover, the results answer our research question: Whereas cognitive activation and supportive climate, the basic dimensions of instructional quality, are-with the aforementioned exceptions-positively related to student competence in accounting, there is no effect of classroom management (time spent on learning in class). Our findings are in line with (a) the predictions derived from prominent models of educational psychology and (b) published research on a cross-sectional basis. Most importantly, we were able to corroborate the significant influence of student mathematics competence (Schumann and Eberle 2014; Seeber 2013; Winther et al. 2013; etc.) and motivational attitudes towards the domain (Kotte and Lietz 1998; Schumann and Eberle 2014). Furthermore, we extended the knowledge about determinants of student academic growth in accounting with regard to student motivation, selfconcept and perception of their accounting teachers' behaviours. Thus, the present study is the first to relate student competence development to motivational regulation (against the background of self-determination theory) and their academic self-concept, and to consider the effects of the three basic dimensions of instructional quality in accounting.

Limitations of the study Regarding the design of the study and the data gathered, we have to point out some issues: First, although we randomly selected the schools and classes for participation in our study and are convinced that the classes selected do not differ much from other Austrian classes, we cannot provide evidence for their representativeness. Second, since we were interested in modelling context effects at the class level, our cluster size of 14 is relatively small and does not allow controlling for different variables at this level; thus, context effects should be interpreted with care. Connected with this problem was the need to employ multiple simple conditional models at level 3 . This increase in the overall number of tests may have led to alpha error accumulation, which might in turn reduce the validity of the results. Third, although we showed that our linearity assumption holds, four measurement waves would be preferable in order to test for non-linearity in growth. Fourth, some predictors, such as teacher behaviour, were assessed at only two occasions, which limits the potential time-varying effect. Moreover, the reliability of some of the variables, such as extrinsic regulation and social learning support, is unsatisfactory according to Cronbach's alpha, which is around 0.60-0.65. One might also question whether using student perceptions to measure teacher behaviour is valid (Clausen 2002; Ditton 2002), or whether observational data from video studies combined with content-related expert ratings would be preferable. Fifth, the present study lacks at least one central predictor, namely student intelligence. Although we tried to compensate for this by including other indicators of student cognitive abilities, and although previous research showed that the effect of intelligence on accounting 
performance is limited, we recommend including this variable in future research. Further missing variables that could explain variation in student competence growth are student learning activities outside school, epistemological beliefs, social interactions in class and, most importantly, content-specific instructional approaches such as how accounting-specific concepts are taught, built and trained, on which further research should focus primarily.

As mentioned in the introduction, accounting instruction in class is often characterised by a focus on training and exercising. Thus, concepts are frequently repeated until students know them by heart and tend to forget about the underlying rules and conditions. An alternative explanation for student competence growth in accounting could therefore be the extent to which rote learning is emphasized in class. From this follows that we need a more elaborated discussion on how "competence" is defined in the context of Austrian accounting students (cf. Winther and Achtenhagen 2008).

Given that insufficient knowledge of controlling and accounting (e.g., debtor management) represents the most common cause for business insolvencies (Bitter and Falk 2009), the lack of research into how young people (in particular those who chose to attend a commercial upper secondary school and are thus more likely to represent future businessmen/women) acquire this knowledge is surprising. We thus argue that the importance of our findings is not only of research interest (since we conducted the first longitudinal study), but also of practical concern: We sought, and were significantly able, to explain how students learn and what determines their growth in accounting competence.

From our findings, we can derive several recommendations for improving daily teaching and learning in this domain: First, prior to introducing students to the subject of Accounting, their mathematical skills (such as modelling real-word problems in mathematical language or auxiliary concepts such as percent calculations) should be trained. Wuttke and Seifried (2012) found that formalisation and mathematisation are among the most frequent student errors in accounting. These deficits (e.g., incorrectly applied arithmetic operations) can be reduced to basic mathematical deficits. Thus, fostering students' mathematical competencies with regard to formalisation and mathematisation provides a solid basis for knowledge building in accounting. Against this background, the integration of the preparatory course in "Business Mathematics" into Accountingwhich was at the same time reduced by $1 \mathrm{~h}$-in Austrian commercial upper secondary schools in 2003/04 needs to be critically examined.

Second, the strong relation between prior knowledge and subsequent performance calls for instruction that strongly emphasises how new concepts are related to what students already know. Although our study did not aim to analyse how central accounting concepts are related to each other, we briefly illustrate what potentially supports knowledge integration:

1. Accounting concepts (in the curriculum under investigation) often share the same skills. Helm et al. (2015a) identified ten skills that students usually apply when doing a book entry for a discount (e.g., formalisation means translating the business case into a book entry, selecting the appropriate accounts, etc.). These skills are common 
to accounting concepts throughout the whole school career and are thus examples of existing schemata that should be considered when integrating new concepts.

2. Concepts often share the same underlying rules; for instance, the imparity realization principle forms the theoretical background of the evaluation of both liabilities and provisions. Again, this common background might represent an existing schema (already learned when liabilities were introduced) to which the new concept of provisions can be linked.

3. Concepts often share similar key terms. For instance, when liabilities are introduced, terms such as "debtor", "debt capital", or "pre-tax deduction" are taught. The new concept of provisions can be connected to these terms/schema. Additionally, our analyses show that classes in which teachers help students to analyse tasks in terms of what is asked, what is given and which prior knowledge students possess develop better than other classes that use less elaborated strategies.

Third, we-like many other researchers-suggest that teachers should seek to support the basic psychological needs of students as much as possible. In this context, good support means that teachers support an appreciative teacher-student relationship, that they enable experience of competence also for weak students (e.g., by considering their prior knowledge when asking them, when giving assignments and tests, or by using methods such as reciprocal teaching) and that teachers provide clear, structured, and understandable instruction. According to the motivation mediation model (Helm 2015), support of basic needs leads to intrinsic motivation, which in turn leads to higher preferable student engagement in learning, which leads to greater competencies.

Finally, our results show that, in addition to our analyses, cognitive activation measured using the items (1) "In Accounting, we often work on learning tasks that allow us to demonstrate that we have really understood the subject matter" and (2) "In Accounting, we often work on learning tasks through which we independently learn new concepts" predicts students' competence. Thus, teachers should aim to cognitively activate instruction by using learning tasks that potentially cognitively activate students. In other words, they should provide students with learning material that encourages them to learn new things independently and that allows them to check whether they have really mastered a concept.

All our suggestions in the previous paragraphs assume that teachers know how to realise them in a meaningful way, which raises content-related didactic issues (e.g., teachers need to know which examples work best in order to convey the usefulness of a specific concept, which in turn raises students' integrated regulation for learning). However, this remains unexplored, and further content-related didactic research is needed.

Compliance with ethical guidelines

Competing interests

The authors declare that they have no competing interests.

\section{Appendix}

See Fig. 2. 


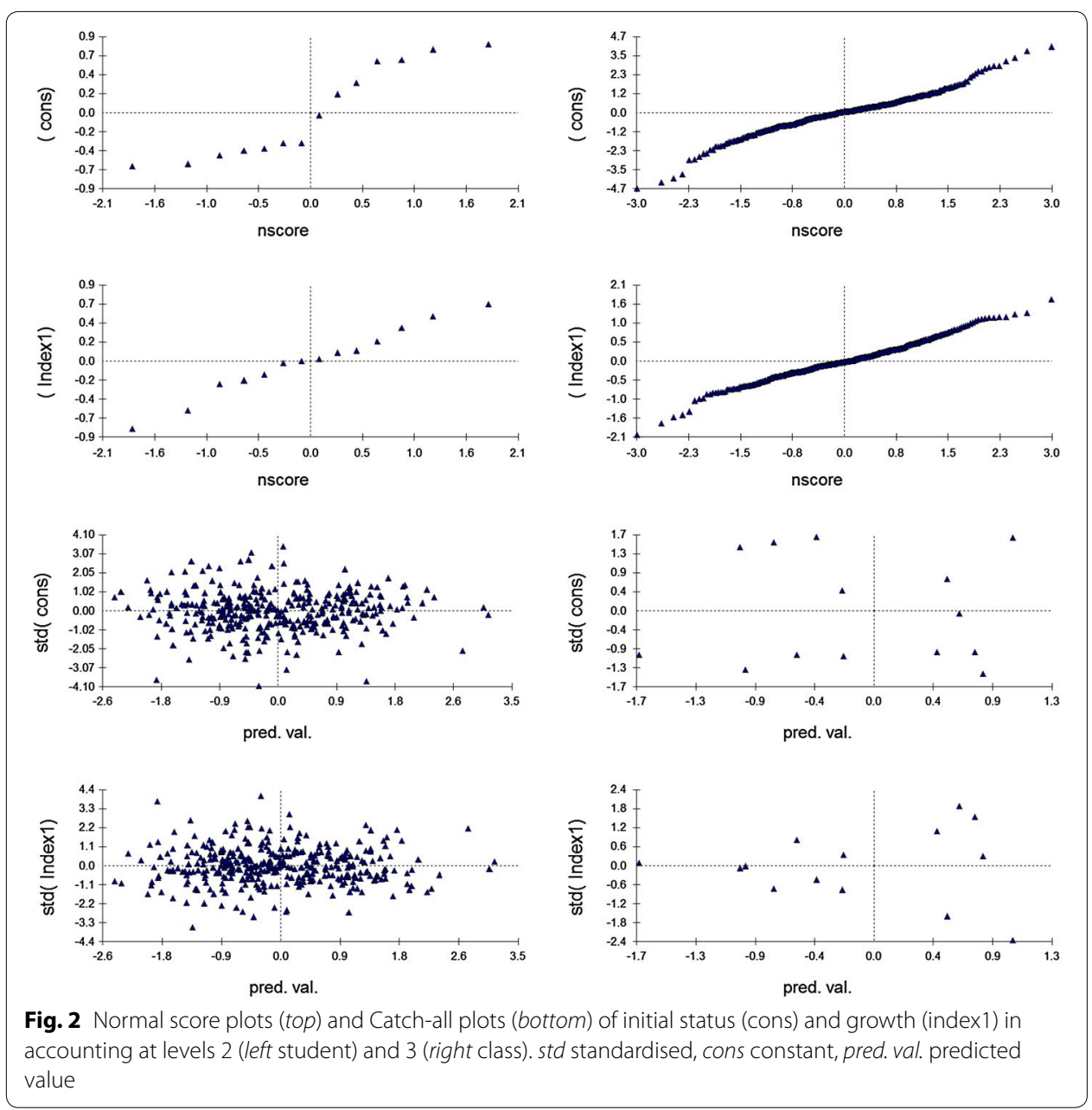

Received: 7 May 2015 Accepted: 22 August 2015

Published online: 23 September 2015

\section{References}

Bacher J, Lachmayr N, Hasengruber K (2008) Empirischer Teil. In: Bacher J, Beham M, Lachmayr N (eds) Geschlechterunterschiede in der Bildungswahl. VS, Wiesbaden, pp 85-148

Beck K, Krumm V (1998) Wirtschaftskundlicher Bildungs-Test (WBT). Hogrefe, Göttingen

Berndt TJ (1997) Child development. Brown and Benchmark, Madison

Biesanz JC, Deeb-Sossa N, Papadakis AA, Bollen KA, Curran PJ (2004) The role of coding time in estimating and interpreting growth curve models. Psychol Methods 9(1):30-52. doi:10.1037/1082-989X.9.1.30

Bitter G, Falk U (2009) Insolvenzen in Zeiten der Finanzkrise. Wirtschaft Konkret 107:1-32

BMBF (2014) Zahlenspiegel 2013. Statistiken im Bereich Schule und Erwachsenenbildung in Österreich. Bundesministerium für Bildung und Frauen, Wien

BMUKK (2010) Entrepreneurship und Management: 13. Schulstufe. Bildungsstandards in der Berufsbildung für Handelsakademien. Kompetenzmodell, Deskriptoren und ausgewählte Unterrichtsbeispiele. Available via http://www. berufsbildendeschulen.at/fileadmin/content/bbs/AGBroschueren/Entrepreneurship_15_03_2010.pdf. Accessed 24 Apr 2015

Bourdieu P (1983) Ökonomisches Kapital, kulturelles Kapital, soziales Kapital. In: Kreckel R (ed) Soziale Ungleichheiten (Soziale Welt, Sonderband 2), Schwartz, Göttingen, pp 183-198

Brandlmaier E, Frank H, Korunka C, Plessnig A, Schopf C, Tamegger K (2006) Ökonomische Bildung von Schülerlnnen allgemeinbildender höherer Schulen: Modellentwicklung, Entwicklung eines Messinstruments, ausgewählte Ergebnisse. WUV, Wien

Brincks A (2012) The implications of centering in a three-level multilevel model: open access Dissertations. Paper 743.

Miami. Available via http://scholarlyrepository.miami.edu/oa_dissertations. Accessed 3 Sept 2015 
Calsyn RJ, Kenny DA (1977) Self-concept of ability and perceived evaluation of others: cause or effect of academic achievement? J Educ Psychol 69(2):136-145

Clausen M (2002) Unterrichtsqualität: Eine Frage der Perspektive?. Waxmann, Münster

Coleman J (1988) Social Capital in the Creation of Human Capital. Am J Sociol 94(Supplement: Organizations and Institutions):95-120

Carroll JB (1963) A model of school learning. Teach Coll Rec 64:723-733

DaQS (n.d.) Datenbank zur Qualität von Schule. Available via http://daqs.fachportal-paedagogik.de/constructlist. Accessed 24 Apr 2015

Deci EL, Ryan RM (1985) Intrinsic motivation and self-determination in human behavior. Plenum, New York

Deci EL, Ryan RM (1993) Die Selbstbestimmungstheorie der Motivation und ihre Bedeutung für die Pädagogik. Zeitschrift für Pädagogik 39(2):223-238

Deci EL, Spiegel NH, Ryan RM, Koestner R, Kauffman M (1982) Effects of performance standards on teaching styles: behavior of controlling teachers. J Educ Psychol 74:852-859

Ditton H (2002) Lehrkräfte und Unterricht aus Schülersicht: Ergebnisse einer Untersuchung im Fach Mathematik. Zeitschrift für Pädagogik 48(2):262-286. Available via http://nbn-resolving.de/urn:nbn:de:0111-opus-38335. Accessed 24 Apr 2015

Dolzanski C (2014) Wie kann die Diskussion über die Weiterentwicklungen der Didaktik des Rechnungswesens voran gebracht werden? Erziehungswissenschaft und Beruf 62(2):213-228

Eder F (1995/2007) Das Befinden von Kindern und Jugendlichen in der Schule. StudienVerlag, Innsbruck

Eder F, Gaisbauer H, Eder C (2002) MATKOMP_-I. Ein Verfahren zur Erfassung mathematischer Kompetenzen. Research Report. Johannes Kepler University of Linz

Ehmke T, Siegle T (2005) ISEI, ISCED, HOMEPOS, ESCS: Indikatoren der sozialen Herkunft bei der Quantifizierung von sozialen Disparitäten. Zeitschrift für Erziehungswissenschaft 8(4):521-540. doi:10.1007/s11618-005-0157-7

Enders CK, Tofighi D (2007) Centering predictor variables in cross-sectional multilevel models: a new look at an old issue. Psychol Methods 12(2):121-138. doi:10.1037/1082-989X.12.2.121

Freundlinger A, Eckstein W-E (1992) Wirtschaftskenntnisse von Maturanten. Research Report, vol 88. IBW, Wien

Götzl M, Jahn RW, Held G (2013) Bleibt alles anders!? Sozialformen, Unterrichtsphasen und echte Lernzeit im kaufmännischen Unterricht. Berufs- und Wirtschaftspädagogik Online, 24. Available via http://www.bwpat.de/ausgabe24/ goetzl_etal_bwpat24.pdf. Accessed 24 Apr 2015

GrolnickWS, Ryan RM (1987) Autonomy in children's learning: an experimental and individual difference investigation. J Pers Soc Psychol 52(5):890-898. doi:10.1037/0022-3514.52.5.890

Haselgruber T (2015) Testkonstruktion zur Erfassung der Kompetenzen von Schüler/inne/n der 11. Schulstufe im Fach Rechnungswesen. Master's thesis, Johannes Kepler University of Linz

Hattie J (2009) Visible learning. Routledge, New York

Heller K, Perleth C (2000) Kognitiver Fähigkeitstest für 4.-12. Klassen, Revision (KFT 4-12+R). Hogrefe, Göttingen

Helm C (2014a) Lernen in Offenen und Traditionellen UnterrichtsSettings (LOTUS). Empirische Analysen zur Kompetenzentwicklung im Fach Rechnungswesen sowie zu förderlichen Elementen kooperativen, offenen Lernens an berufsbildenden mittleren und höheren Schulen in Österreich. Dissertation, Johannes Kepler University of Linz

Helm C (2014b) Cooperative open learning in commercial education: multilevel analysis of first grade students' learning outcomes. Reflecting Educ 9(2):63-84

Helm C (2015) Reziproke Effekte zwischen wahrgenommenem Lehrerverhalten, intrinsischer Motivation und der Schülerleistung im Fach Rechnungswesen. AMS report 111. Available via http://www.forschungsnetzwerk.at/downloadpub/AMS_report_111.pdf. Accessed 2 Sept 2015

Helm C (in press) Berufsbildungsstandards und Kompetenzmodellierung im Fach Rechnungswesen. In: Bundesinstitut für Berufsbildung (eds) Bildungsstandards und Kompetenzorientierung. Herausforderungen und Perspektiven der Bildungs- und Berufsbildungsforschung

Helm C, Bley S, George AC, Pocrnja M (2015a) Potentiale kognitiver Diagnosemodelle für den berufsbildenden Unterricht. In: Stock M, Schlögl P, Schmid K, Moser D (eds) Kompetent - wofür? Life-Skills - Beruflichkeit - Persönlichkeitsbildung. StudienVerlag, Innsbruck, pp 206-224

Helm C, Kemethofer D, Altrichter H, Weber C (2015b) anonymised for peer-reviewEffekte der NMS-Konzeptmerkmale auf die fachlichen Schülerleistungen. In: Eder F, Altrichter H, Bacher J, Hofmann F, Weber C (eds) Bericht über die Evaluierung der „Neuen Mittelschule“ (NMS). Befunde aus den Anfangskohorten. Research Report, Salzburg and Linz, pp 279-298

Helmke A (2009) Unterrichtsqualität und Lehrerprofessionalität. Diagnose, Evaluation und Verbesserung des Unterrichts. Klett-Kallmeyer, Seelze-Velber

Helmke A, Schrader F-W (2006) Lehrerprofessionalität und Unterrichtsqualität. Schulmagazin 5-10(9):5-12

Helmke A, van Aken MAG (1995) The causal ordering of academic achievement and self-concept of ability during elementary school a longitudinal study. J Educ Psychol 87(4):624-637

Hunt E (2000) Let's hear it for crystallized intelligence. Learn Individ Diff 12(1):123-127

Iverson BK, Walberg HJ (1982) Home environment and learning: a quantitative synthesis. J Exp Educ 50(3):144-151

Jang H, Kim EJ, Reeve J (2012) Longitudinal test of self-determination theory's motivation mediation model in a naturally occurring classroom context. J Educ Psychol 104(4):1175-1188

Jordan VB, Brownlee L (1981) Meta-analysis of the relationship between Piagetian and school achievement tests. Paper presented at the annual meeting of the American Educational Research Association, Los Angeles, CA, 13-17 Apr 1981

Kerschensteiner G (1904) Berufs- oder Allgemeinbildung? In: Wehle G (ed) Georg Kerschensteiner. Berufsbildung und Berufsschule. Ausgewählte Pädagogische Schriften. Schöningh, Paderborn, pp 89-104

Klieme E, Lipowsky F, Rakoczy K, Ratzka N (2006) Qualitätsdimensionen und Wirksamkeit von Mathematikunterricht. Theoretische Grundlagen und ausgewählte Ergebnisse des Projekts "Pythagoras". In: Prenzel M (ed) Untersuchungen zur Bildungsqualität von Schule. Abschlussbericht des DFG-Schwerpunktprogramms BIQUA (Bildungsqualität von Schule). Waxmann, Münster, pp 127-146 
Klieme E, Pauli C, Reusser K (2009) The Pythagoras Study: Investigating effects of teaching and learning in Swiss and German mathematics classrooms. In: Janík T (ed) The power of video studies in investigating teaching and learning in the classroom. Waxmann, Münster, pp 137-160

Kolen MJ, Brennan RL (2004) Test equating, scaling, and linking: Methods and practices. Statistics for social science and public policy, 3rd edn. Springer, New York

Konrad K (2008) Erfolgreich selbstgesteuert lernen. Theoretische Grundlagen, Forschungsergebnisse, Impulse für die Praxis. Klinkhardt, Bad Heilbrunn

Kotte D, Lietz P (1998) Welche Faktoren beeinflussen die Leistung in Wirtschaftskunde? Zeitschrift für Berufs- und Wirtschaftspädagogik 94(3):421-434

Kuncel NR, Hezlett SA, Ones DS (2001) A comprehensive meta-analysis of the predictive validity of the graduate record examinations: implications for graduate student selection and performance. Psychol Bull 127(1):162-181

Kuncel NR, Hezlett SA, Ones DS (2004) Academic performance, career potential, creativity, and job performance: can one construct predict them all? J Pers Soc Psychol 86(1):148-161. doi:10.1037/0022-3514.86.1.148

Lehmann R, Seeber S (2007) ULME III. Untersuchung der Leistungen, Motivation und Einstellungen der Schülerinnen und Schüler in den Abschlussklassen der Berufsschulen. Polyprint, Berlin

Linn RL, Hastings CN (1984) A meta analysis of the validity of predictors of performance in law school. J Educ Meas 21(3):245-259. doi:10.1111/j.1745-3984.1984.tb01032.x

Maas CJM, Hox JJ (2005) Sufficient Sample sizes for multilevel modeling. Methodology 1(3):86-92

Mair P, Hatzinger R, Maier M (2011) eRm: Extended Rasch Modeling. R package version 0.14-0. Available via http:// CRAN.R-project.org/package $=$ eRm. Accessed 3 Sept 2015

Mandl H, Fischer P (1982) Wissenschaftliche Ansätze zum Aufbau und zur Förderung selbstgesteuerten Lernens. Unterrichtswissenschaft 2:111-118

Metzger C (2014) Selbstlernkompetenz von Berufslernenden—Legitimation einer intensiven Förderung. In: Naeve-Stoss N, Seeber S, Brand W (eds) Digitale Festschrift für TADE TRAMM zum 60. Geburtstag, pp 1-16. Available via bwp@ de. Accessed 24 Apr 2015

Metz-Göckel H (2001) Lernmotivation in der kaufmännischen Erstausbildung. In: Beck K, Krumm V (eds) Lehren und Lernen in der beruflichen Erstausbildung. Grundlagen einer modernen kaufmännischen Berufsqualifizierung, Leske+Budrich, Opladen, pp 63-75

Müller F, Hanfstingl B, Andreitz I (2007) Skalen zur motivationalen Regulation beim Lernen von Schülerinnen und Schülern: Adaptierte und ergänzte Version des Academic Self-Regulation Questionnaire (SRQ-A) nach Ryan and Connell. Research Reports. Alpen-Adria-University of Klagenfurt

Muthén LK, Muthén BO (1998-2014) Mplus user's guide. (Version 7). Muthén and Muthén, Los Angeles

Ntoumanis N (2014) Analysing longitudinal data with multilevel modelling. Eur Health Psychol 16(2):40-45

Nüesch C, Metzger C (2010) Lernkompetenzen und ihr Zusammenhang mit motivationalen Überzeugungen und Lernleistungen in der kaufmännischen Berufsausbildung. Zeitschrift für Berufs- und Wirtschaftspädagogik 106(1):36-51

OECD (Ed) (2012) Education at a Glance 2012: OECD Indicators. Paris, Washington: Organization for Economic Cooperation and Development; Brookings Institution Press [Distributor]

Phillipson S, Phillipson SN (2012) Children's cognitive ability and their academic achievement: the mediation effects of parental expectations. Asia Pacific Educ Rev 13(3):495-508. doi:10.1007/s12564-011-9198-1

Piaget J (1929) The child's conception of the world. Routledge and Kegan Paul, London

Piaget J (1970) Piaget's theory. In: Mussen PH (ed) Handbook of child psychology. Wiley, New York, pp 703-732

Plinke W (2013) Plädoyer für eine funktions- und nutzenorientierte Rechnungswesendidaktik. Erziehungswissenschaft und Beruf 61:14-31

Prenzel M, Drechsel B, Kliewe A, Kramer K, Röber N (2000) Lernmotivation in der Aus- und Weiterbildung: Merkmale und Bedingungen. In Harteis $\mathrm{C}$, Heid H, Kraft S (eds) Kompendium Weiterbildung. Aspekte und Perspektiven betrieblicher Personal- und Organisationsentwicklung, Leske+Budrich, Opladen, pp 163-173

Rasbash J, Charlton C, Browne WJ, Healy M, Cameron B. (2009) MLwiN Version 2.1. Centre for Multilevel Modelling, University of Bristol

Reeve J, Jang H (2006) What teachers say and do to support students'autonomy during a learning activity. J Educ Psychol 98(1):209-218

Rizopoulos D (2006) Itm: an R package for latent variable modelling and item response theory analyses. J Stat Soft 17(5): 1-25. Available via http://www.jstatsoft.org/v17/i05/. Accessed 3 Sept 2015

Ryan RM, Connell JP (1989) Perceived locus of causality and internalization: examining reasons for acting in two domains. J Pers Soc Psychol 57(5):749-761. doi:10.1037/0022-3514.57.5.749

Sageder J (1995) Abschlussbericht zum Forschungsprojekt, Entwicklung eines Verfahrens zur Messung des Lern- und Studierverhaltens'. Research Report. Johannes Kepler University of Linz

Schiefele U, Pekrun R (1996) Psychologische Modelle des fremdgesteuerten und selbstgesteuerten Lernens. In: Weinert FE (ed) Psychologie des Lernens und der Instruktion. Hogrefe, Göttingen, pp 249-278

Schneider W, Körkel J, Weinert F (1989) Domain-Specific Knowledge and Memory Performance. J Educ Psychol 81:306-312

Schrader F-W, Helmke A (2008) Determinanten der Schulleistung. In: Schweer MKW (ed) Schule und Gesellschaft. Lehrer-Schüler-Interaktion. Inhaltsfelder, Forschungsperspektiven und methodische Zugänge, VS, Wiesbaden, pp 286-302

Schumann S, Eberle F (2014) Ökonomische Kompetenzen von Lernenden am Ende der Sekundarstufe II. Zeitschrift für Erziehungswissenschaft 17(1):103-126. doi:10.1007/s11618-013-0459-0

Schunk DH, Zimmerman BJ (2008) Motivation and self-regulated learning: theory, research, and applications. Erlbaum, New York

Schwarzer R, Jerusalem M (2002) Das Konzept der Selbstwirksamkeit. In: Jerusalem M, Hopf D (eds) Selbstwirksamkeit und Motivationsprozesse in Bildungsinstitutionen. Beltz, Weinheim, pp 28-53 
Seeber S (2008) Ansätze zur Modellierung beruflicher Fachkompetenz in kaufmännischen Ausbildungsberufen. Zeitschrift für Berufs- und Wirtschaftspädagogik 104(1):74-97

Seeber S (2013) Zum Einfluss mathematischer Kompetenzen auf den Übergang in eine berufliche Ausbildung und auf die Entwicklung beruflicher Fachkompetenzen im kaufmännischen Bereich. Zeitschrift für Berufs- und Wirtschaftspädagogik. Beihefte. 26. Mathematisch-naturwissenschaftliche Kompetenzen in der beruflichen Erstausbildung, Steiner, Stuttgart, pp 67-93

Seeber S, Lehmann R (2013) Basic competencies as determinants of success in commercial apprenticeships. In: Beck K, Zlatkin-Troitschanskaia O (eds) From diagnostics to learning success. Sense Publishers, Rotterdam, pp 75-84

Seeber S, Nickolaus R, Winther E, Achtenhagen F, Breuer K, Frank I, Zöller A (2010) Kompetenzdiagnostik in der Berufsbildung. Berufsbildung in Wissenschaft und Praxis—BWP 1:1-15

Seifried J (2004) Fachdidaktische Variationen in einer selbstorganisationsoffenen Lernumgebung: Eine empirische Untersuchung des Rechnungswesenunterrichts. Deutscher Universitäts-Verlag, Wiesbaden

Sembill D (2004) Abschlussbericht für das im Rahmen des DFG-Schwerpunktprogramms: „Lehr-Lern-Prozesse in der kaufmännischen Erstausbildung“durchgeführte DFG-Projekt „Prozessanalysen Selbstorganisierten Lernens". Available via http://www.uni-bamberg.de/fileadmin/uni/fakultaeten/sowi_lehrstuehle/wirtschaftspaedagogik/ Dateien/Forschung/Forschungsprojekte/Prozessanalysen/DFG-Abschlussbericht_sole.pdf. Accessed 3 Sept 2015

Singer JD, Willett JB (eds) (2003) Applied longitudinal data analysis: Modeling change and event occurrence. Oxford University Press, New York

Snijders TAB, Bosker RJ (2000) Multilevel analysis: An introduction to basic and advanced modeling. Sage Publications, London

Staub FC, Stern E (2002) The nature of teachers' pedagogical content beliefs matters for students'achievement gains quasi-experimental evidence from elementary mathematics. J Educ Psychol 94(2):344-355

Stern E (2003) Lernen ist der mächtigste Mechanismus der kognitiven Entwicklung: Der Erwerb mathematischer Kompetenzen. In: Schneider W, Knopf M (eds) Entwicklung, Lehren und Lernen: Zum Gedenken an Franz Emanuel Weinert. Hogrefe, Göttingen, pp 207-217

Stock M (2014) Kaiserin Maria Theresia und die Wirtschaftspädagogik. wissenplus 5-13/14:13-17

Stommel A (2014) Die schöne, neue Welt des „Neuen Rechnungswesens". Erziehungswissenschaft und Beruf 62(2):229-239

Um EK, Corter JE, Tatsuoka K (2005) Motivation, autonomy support, and mathematics performance: A structural equation analysis. Available via http://cms.tc.columbia.edu. Accessed 24 Apr 2015

Valås H, Søvik N (1993) Variables affecting students' intrinsic motivation for school mathematics: two empirical studies based on Deci and Ryan's theory on motivation. Learn Instruction 3(4):281-298. doi:10.1016/0959-4752(93)90020-Z

Vansteenkiste M, Simons J, Lens W, Sheldon KM, Deci EL (2004) Personality processes and individual differences—motivating learning, performance, and persistence. The synergistic effects of intrinsic goal contents and autonomysupportive contexts. J Pers Soc Psychol 87(2):246-259

Vansteenkiste M, Simons J, Lens W, Soenens B, Matos L (2005) Examining the motivational impact of intrinsic versus extrinsic goal framing and autonomy-supportive versus internally controlling communication style on early adolescents'academic achievement. Child Dev 76(2):483-501

Vygotskij LS (ed) (1978) Mind in society: The development of higher psychological processes. Harvard Univ. Press, Cambridge

Walberg HJ (1981) A psychological theory of educational productivity. In: Farley FH, Gordon NJ (eds) Psychology and Education. McCutachan, Berkeley, pp 81-108

Williams GC, Grow VM, Freedman ZR, Ryan RM, Deci EL (1996) Motivational Predictors of Weight Loss and Weight-Loss Maintenance. J Pers Soc Psychol 70(1):115-126

Winther E (2006) Motivation in Lernprozessen: Konzepte in der Unterrichtspraxis von Wirtschaftsgymnasien. Deutscher Universitäts-Verlag, Wiesbaden

Winther E (2010) Kompetenzmessung in der beruflichen Bildung. Bertelsmann, Bielefeld

Winther E, Achtenhagen F (2008) Kompetenzstrukturmodell für die kaufmännische Bildung: adaptierbare Forschungslinien und theoretische Ausgestaltung. Zeitschrift für Berufs- und Wirtschaftspädagogik 104(4):511-538

Winther E, Sangmeister J, Schade AK (2013) Zusammenhänge zwischen allgemeinen und beruflichen Kompetenzen in der kaufmännischen Erstausbildung. In Zeitschrift für Berufs- und Wirtschaftspädagogik. Beihefte. 26. Mathematisch-naturwissenschaftliche Kompetenzen in der beruflichen Erstausbildung. Steiner, Stuttgart, pp 139-160

Wuttke E, Seifried J (2012) Ansätze der Identifikation typischer Schülerfehler-Ergebnisse aus Studien in kaufmännischen Schulen. Unterrichtswissenschaft 40(2):174-192 